\title{
What is the added value of including fleet dynamics processes in fisheries models?
}

\author{
Paul Marchal ${ }^{a}{ }^{\text {, }}$, José A.A. De Oliveira ${ }^{b}$, Pascal Lorance ${ }^{c}$, Loïc Baulier ${ }^{d}$, Lionel Pawlowski ${ }^{d}$ \\ a IFREMER (I'Institut Francais de Recherché Pour l'Exploitation de La Mer), Channel and North Sea Fisheries \\ Research Unit, 150 Quai Gambetta, BP 699, 62321 Boulogne s/mer, France. \\ ${ }^{\mathrm{b}}$ CEFAS (Centre for Environment Fisheries and Aquaculture Science), Pakefield Road, Lowestoft, Suffolk NR33 \\ ${ }^{c}$ IFREMER, Fisheries Ecology and Modelling, Rue de l'lle d'Yeu, BP 21105, 44311 Nantes Cedex 03, France. \\ d IFREMER, Fisheries Science and Technology Unit, 8 Rue François Toullec, BP 699, 56100 Lorient, France. \\ *: Corresponding author : Paul Marchal, email address : paul.marchal@ifremer.fr
} OHT, United Kingdom.

\begin{abstract}
:
We develop a spatially and seasonally explicit bioeconomic model with three fleet dynamics processes built in endogenously. The model has been applied to the large French trawlers harvesting a mediumdepth demersal stock, North Sea saithe (i.e., pollock, Pollachius virens), and a mix of deepwater species over a 10-year period (1999-2008), and the predictions have been contrasted with observations. The best overall fit was achieved where effort allocation was determined to be $80 \%$ by traditions and $20 \%$ by economic opportunism and where harvest efficiency increased by $8 \%$ a year. With this fleet dynamics parameterization, annual trends in fishing effort and profit were well reproduced by the model over the whole time period. Time series of the observed fishing effort by métier were generally well fitted by the model over the period 1999-2003, but less so over 2004-2008. The model also reasonably reproduced the catches by species over most of the time series, except for black scabbardfish (Aphanopus carbo).
\end{abstract}

\section{Résumé:}

Nous développons un modèle bio-économique spatial et saisonnier dans lequel trois processus caractérisant la dynamique des flottilles sont décrits de manière explicite. Ce modèle a été appliqué aux grands chalutiers français exploitant le lieu noir de mer du Nord (Pollachius virens) et une variété d'espèces profondes au cours d'une période de 10 ans (1999-2008), et les prévisions ont été contrastées avec les observations. Le meilleur ajustement est obtenu lorsque l'allocation de l'effort de pêche est déterminée à hauteur de $80 \%$ par les traditions et $20 \%$ par l'opportunisme économique, et lorsque l'augmentation de l'efficacité de pêche est d'environ $8 \%$ par an. En paramétrant ainsi le module de dynamique des flottilles, les tendances annuelles de l'effort de pêche et du profit sont bien reproduites par le modèle sur l'ensemble de la période. Les variations temporelles de l'effort de pêche par métier sont généralement bien prises en compte sur la période 1999-2003, mais non sur la période 2004-2008. Le modèle ajuste les captures raisonnablement sur la plus grande partie de la période d'étude, pour toutes les espèces sauf le sabre noir (Aphanopus carbo). 


\section{Introduction}

The performances of fisheries management rely to a large extent on how well one is able to evaluate and forecast the combined ecological and socio-economic impacts of management measures. In the EU, every proposal for new management measures/regulations must now go through a process referred to as an impact assessment (EC 2009). Well-founded and operational models are central to the impact assessment procedure. In the fisheries domain, biological models exist and are commonly used to provide single-species TAC (Total Allowable Catches) advice (Beverton and Holt 1957; Hilborn and Walters 1992). However, while such models are reasonably founded to provide short-term predictions (e.g. one year ahead), they are clearly inadequate to predict the longer-term impacts of management regulations (Brander 2003). Understanding long-term impacts requires integrating environmental, ecological, economic and social processes into holistic models. Examples of such processes include the dynamics of recruitment, ecosystem functioning, market fluctuations, fishing fleets and management actions.

Numerous bio-economic models (BEMs) have been developed by the community of fisheries scientists and economists, since the early works of Gordon (1953) and Schaefer (1957). Until the beginning of this century, however, and with rare exceptions, the biological and the economic components of BEM were unequally considered, depending on the main field of expertise of the lead scientist in charge of their development. Fishery economists typically focused on such processes as price setting, fleet, effort and cost dynamics, often in a profitmaximization fashion, but with limited efforts to account for the complexity of fish population dynamics, which were often included as an aggregated production function (Clark 1980; Ganguly and Chaudhuri 1995; Garza-Gil 1998). By contrast, fishery scientists involved in stock assessments have developed management procedures using detailed age-structured models building in recruitment dynamics, but with little consideration for cost and price dynamics, or for the economic processes driving fleet and effort dynamics (Horwood et al. 1990; Punt and Butterworth 1991; Marchal 1997).

Things have changed in the last decade, and there has been a genuine effort from the various research communities to combine their respective expertise into more truly integrated BEM (Prellezo et al. 2012). Examples of such integrated models have been proposed for many fisheries worldwide including the US (Overholtz et al. 1995; Holland 2000; Holland 2003), Australia (Little et al. 2009) and New Zealand (Holland and Herrera 2006; Marchal et al. 2009a).

A number of integrated BEM have also been developed recently and applied to a variety of EU mixed fisheries case studies. Some of these bio-economic models are spatially and seasonally explicit. These include e.g. the ISIS-Fish modeling platform (Mahévas and Pelletier 2004; Pelletier and Mahévas 2005; Marchal et al. 2011), the TEMAS program (Ulrich et al. 2007; Andersen et al. 2010), and the extensive spatial FLR model (Bastardie et al. 2010a; Bastardie et al. 2010b). Such models have been designed to evaluate combined economic and spatial effects of administrative and economic (or incentive-based) management with special attention to fishers' responses to such regulations, but also to fish stock distribution and market conditions (e.g. oil price, interest rates, fish market prices).

However, despite all the efforts made to incorporate and combine the complex dynamics of ecological and economic processes into holistic BEMs, most of these models have essentially been developed with an academic purpose, and there are only few cases where they have been used operationally by decision-makers to provide integrated advice and to inform long-term management (Kompas et al. 2010). This is mainly because the complexity of the BEMs being developed has hindered the validation of their predicted ecological and 
economic outputs against actual observations, giving fisheries managers and advisers the impression that BEM forecasting is a useful but still mostly academic exercise.

In many studies found in the fisheries research literature, BEMs have been developed in an exploratory fashion, and their outcomes were not contrasted with observations (Laurec et al. 1991; Drouineau et al. 2006; Hoff and Frost 2008). In other bioeconomic modelling studies, some of the BEM outputs (e.g., catches, fishing effort) were validated against observations, sometimes at a rather disaggregated level (Andersen et al. 2010; Bastardie et al. 2010b). However, the BEM developed in these studies were parameterized using the same information and data period which was used to evaluate the model"s goodness of fit. In rare occasions, bioeconomic model forecast were successfully contrasted several years ahead against data that were not used to calibrate the model (Little et al. 2009). However, the case investigated by Little et al. (2009) was a relatively simple and data-rich fishery with few species caught, and the comparison between forecast and observed values was performed with aggregated variables (total annual fishing effort and catch per species), and not at a more disaggregated level.

Many fisheries worldwide are subject to complex technical interactions, and are often referred to as mixed fisheries. Mixed fisheries typically consist of fishing fleets operating a wide spectrum of fishing activities (or métiers), and targeting a large panel of species. A central process that needs to be intimately captured and subsequently modelled is then the dynamics of such flexible and opportunistic fishing fleets. Fisheries scientists have hence claimed for a long time that accounting for fleet dynamics was an indispensable step to evaluating management options and performing long-term fisheries forecasts (Hilborn 1985; Branch et al. 2006; Reeves et al. 2008). As a result, considerable efforts have been dedicated in the past twenty-five years to the development of fleet dynamics models using discrete-choice models (Holland and Sutinen 1999; Vermard et al. 2008; Marchal et al. 2009b), or different other conceptual approaches (Gillis 2003; Bertrand et al. 2005; Poos and Rijnsdorp 2007), particularly in the context of evaluating the bioeconomic performances of spatial management (Sanchirico and Wilen 2005; Smith et al. 2008; Haynie and Layton 2010). To evaluate the extent to which including fleet dynamics into BEMs would not only change the perception, but also the credence of resulting fisheries forecasts would require to ensure that such models are able to reproduce, not only the annual variations of some aggregated key variables (e.g. catches and fishing effort per fishing fleet), but also exploitation shifts at a more disaggregated level (e.g., catches and fishing effort by métier).

To add to the complexity of the mixed fisheries bioeconomic modelling exercise, the level of information available for the different species targeted may vary, typically between those species for which an analytical stock assessment is available (data-rich species), and those on which information is rather poor (data-limited species). Many modelling studies have restricted their biological model to data-rich species, the parameters of which could be easily calibrated against available stock assessment outputs. Still, data-limited species may represent a substantial contribution to the landing value, and their dynamics should not be ignored.

To our best knowledge, the exercise of validating BEM outputs at a disaggregated (métier) level has not been performed in complex mixed fisheries, including several fleets, several métiers, and several species for which information is variable. In this study, we developed a spatially- and seasonally-explicit bioeconomic model with three essential elements of fleet dynamics built in endogenously: changes in fleet size, effort allocation, and harvest efficiency (Hilborn 1985). We selected for the purpose of this investigation the complex French deepsea mixed fishery to the West of the British Isles. The model has been run over a ten-year period (1999-2008) where biological, harvest and economic data were available. Several key processes of our BEM were calibrated against the 1999-2008 data, including recruitment, fleet capacity, fish prices and operating costs. Fishing effort and catches per métier, 
however, were only initiated in 1999, the first simulated year, and then forecast using our BEM over the period 2000-2008. Per métier and monthly catch and fishing effort forecast were then contrasted with actual 2000-2008 observations that were not used in the calibration using different fleet dynamics models and parameterizations. The extent to which the inclusion of one or the other fleet dynamics models improved the predictability of our BEM was then quantified using the residuals sum of squares criterion.

\section{Materials and methods}

\subsection{Background}

Deepwater fishing to the West of the British Isles started in the late 1980s. The fishery was initiated by large French trawlers targeting saithe (Pollachius virens) in medium depth waters (200-400 m), which moved on towards deeper areas to harvest blue ling (Molva dypterygia), roundnose grenadier (Coryphaenoides rupestris), black scabbardfish (Aphanopus carbo), orange roughy (Hoplosthetus atlanticus), and deepwater sharks (Centrophorus squamosus and Centroscymnus coelolepis). With the exception of blue ling, the upper distribution part (i.e., $<200 \mathrm{~m}$ ) of which has been harvested since at least the 1950s, catches from all other deepwater species were anecdotal until 1990 (Charuau et al., 1995). Other countries, mainly Ireland, Spain, the Faeroe Islands and the UK, have joined in the deepwater venture since 1990. The fishery was subject to little regulation until 2003, when the EU enforced a series of management measures including TACs, area closures, fishing licenses, and direct monitoring via on-board observers. However, many of these stocks had severely declined by then, particularly orange roughy, which is almost absent from catches nowadays (ICES 2011b).

Despite other fleets and countries joining in, French trawlers over $40 \mathrm{~m}$ have been the main contributors to deepwater fishing off the Western British Isles over the past 20 years. The large French trawlers have often contributed to more than half of the landings of deepwater species (blue ling, roundnose grenadier, black scabbardfish, deepwater sharks) since the start of their exploitation. However, deepwater fish are not the only target species of the large French trawlers. In fact, about $40 \%$ of their landed value (in euros) consists of saithe, while deepwater species contribute to only $30 \%$ of the total harvest value. The remaining $30 \%$ of the total gross revenue result from landing other species.

\subsection{Data}

\subsubsection{Biological information}

This study focuses on saithe, blue ling, roundnose grenadier, black scabbardfish and deepwater sharks. The North Sea and West of Scotland saithe stock considered here is distributed over ICES (International Council for the Exploration of the Sea) Subareas IV, VI and Division IIIa, and is subject to a regular age-structured stock assessment (ICES 2011a) with recruitment at age 3 , and age 10 as plus-group. The Southern blue ling stock covers ICES Divisions Vb and Subareas VI and VII (ICES 2011b). Fish smaller than $80 \mathrm{~cm}$ are rarely caught, and recruitment is generally considered to occur at age 7 . Blue ling spawning areas have been mapped by Large et al. (2010), and the peak of the spawning season is considered to occur between March and May. The lack of a formal agreement on agereading and of a well-founded tuning index has hindered ICES from carrying out an agestructured stock assessment for Southern blue ling. Different growth curves have been suggested in the literature, however (Ehrich and Reinsch 1985; Thomas 1987; Magnussen 2007), and cpue-based abundance indices have recently been developed by Lorance et al. (2010) using advanced standardization methods. We have used this information as a basis to perform an exploratory XSA (eXtended Survivors Analysis) assessment (Shepherd 1999) 
for the Southern blue ling stock over the period 1999-2008. Natural mortality, weights at age, exploitation pattern, recruitment (1999-2008), and abundance numbers at age in 1999 used in, or derived from, the blue ling and the saithe stock assessments are given in Tables 1 and 2.

The black scabbardfish stock considered here is distributed over ICES Division $\mathrm{Vb}$ and Subareas VI and VII (ICES 2011b). The roundnose grenadier stock is considered covering the same areas, but also ICES Divisions XIlb (western Hatton Bank) (ICES 2011b). Deepwater sharks are distributed over the whole Northeast Atlantic and they are assessed as one stock, although they are composed of two different species, Centrophorus squamosus and Centroscymnus coelolepis (ICES 2011c). However, it is important to understand that the definition of these deepwater species assessments units is still uncertain, and a number of studies have suggested these do not necessarily match populations structuring (White et al. 2010; Longmore et al., 2011; Verissimo et al., 2011). There is overall insufficient information to carry out an age-structured assessment for these stocks. ICES (2011b) has carried out an exploratory stock assessment for roundnose grenadier building on a Schaefer production model. ICES has not carried out any form of analytical assessment in relation to black scabbardfish and deepwater sharks since 2002. In this study, we have fitted a Schaefer production model, using a standardized French cpue index, over the period 1999-2008, to get some insights into the dynamics of these stocks. The estimated carrying capacity, growth rate and biomass in 1999 are shown in Table 3 for roundnose grenadier, black scabbardfish and deepwater sharks.

\subsubsection{Fleets information}

Three fishing fleets (i.e. set of fishing vessels of similar physical characteristics) were implemented in this investigation. The first fleet consists of large French trawlers (exceeding $40 \mathrm{~m}$ in length), and the second of all other (smaller) French vessels, in both cases catching at least $1 \mathrm{~kg}$ of the species under consideration. These are hereafter referred to as the large French trawlers fleet and the other French fleet, respectively. The third fleet is composed of all other vessels, which have harvested the non-French component of the international catches of saithe and deepwater species over the period 1999-2008. It is hereby referred to as the non-French fleet. These three fleets have been implemented differently in the BEM, depending on information available and on their contribution to deepwater fishing.

Detailed catch and effort data were available for the two French fleets over the period 19992008. These data were extracted from fishers" logbooks and fish auction market statistics registered by the French Directorate for Sea Fisheries and Aquaculture and extracted from Harmonie, the database of the French Fisheries Information System managed by Ifremer, the French Research Institute for the Exploitation of the Sea. Data are available by vessel, fishing trip, statistical rectangle [surface: $1^{\circ}$ longitude $\times 0.5^{\circ}$ latitude or $\sim 30$ nautical miles (hereafter referred to as miles) $\times 30$ miles $(1$ mile $=1.853 \mathrm{~km})$ ], and gear used. The recorded vessels characteristics are length, tonnage, and horsepower. The type of gear and, for most vessels, the mesh size used, were also made available. No such data could be made available for the non-French fleet over the period being considered. However, non-French catches for all the species under investigation could be derived annually from ICES (2011a, b, c) over 1999-2008. The contribution of the three fleets to the different species" catch is shown in Table 2. The annual number of vessels and of hours fished per vessel is shown in Table 4 for the two French fleets under investigation.

Annually operating costs could be made available for the large French trawlers over the period 2002-2008 (JRC 2010). Operating costs over the period 1999-2001 were extrapolated as the 2002-2008 average. These covered the costs of both travelling to and from the fishing grounds, and of the fishing operations. Monthly fish landing prices were derived from the 
French fisheries auction database, and these were assumed constant across métiers. Gross revenue and profit over the period 1999-2008 were derived by combining logbooks" landings and effort, sale slips" fish prices and operating costs. Economic data available to this study are summarized in Tables 2 (fish prices) and 4 (operating costs, gross revenue, profit). Profits were generally negative over the period 1999-2008, mainly due to excess capacity combined with a strong decline in the biomass of valuable deep-sea stocks (ICES 2011b), resulting in a halving of the fleet size from 25 vessels in 1999 to 13 vessels in 2008. Decommissioning schemes from the EU Multi-Annual Guidance programme that were in force until 2004 might also, although to an unknown extent, have contributed to the fleet size decline (Guyader and Daurès 2000). In fact, it is perhaps noticeable that a number of fishing vessels still continued fishing when they could apparently not cover their operating costs, which deserves some comments. Catch limits were established for most deepwater species in 2003. Skippers could then have been incited by producers organizations (which manage catch quotas in France) to increase their deepwater species catch history over the period preceding TAC enforcement (i.e., 1999-2002 in our case), despite immediate low profits, so to increase their quota share and thereby expect higher profits in the future. Such hopes for a better future might have prevailed over the current economic situation, and encouraged companies to maintain a deepwater fishing activity despite poor recent profits (Guyader et al. 2004). No economic information could be made available for the other French and the nonFrench fleets.

Over the period 1999-2008, the large French trawlers have been one of the main French suppliers of deepwater species" landings, but their contribution to international saithe landings has been more limited (Table 2). The dynamics of this fleet are largely determined by saithe and deepwater species, but other species contribute substantially (25-36\%) to the overall gross revenue (Table 4). The other French fleet has generally a more limited contribution to the catches of saithe and deepwater species (Table 2), and its dynamics are overwhelmingly determined by other species, which are not modeled explicitly here. Finally, the non-French fleet is generally the main contributor of saithe and deepwater sharks landings and, in some years, blue ling.

\subsubsection{Métiers information}

Fishing fleets may operate different activities, depending on the gear they use, the fishing ground they visit, and/or the species they target. The term "métier" has sometimes been suggested to define a type of fishing activity (ICES 2003). A métier is a group of vessel voyages targeting the same (assemblage of) species and/or stocks, using similar gear, during the same period of the year and within the same area. We considered here that both French fleets could operate ten métiers each. These included the six deepwater métiers identified by Lorance et al. (2010) (DeepEdge6, DeepNew5, DeepNew6, DeepOther6, DeepRef5 and DeepRef7 in Table 5), and four additional demersal métiers operated by the two French fleets in shallower waters (Dem4, Dem5, Dem6 and Dem78 in Table 5). The fishing effort of large French trawlers has mainly been allocated to métier Dem4 (saithe fishing) and to the traditional deepwater métiers DeepEdge6, DeepOther6 and DeepRef5, over the period 1999-2008. Less fishing effort has been allocated to the other métiers. Almost all (>92\%) of the fishing effort operated by the other French fleet is allocated to métier Dem78. No information was available on the métiers operated by the non-French fleet.

\subsubsection{Management information}

Over the period 1999-2004, the capacity of all EU fishing fleets was capped by a series of multi-annual targets established within the fourth Multi-Annual Guidance Programme (MAGP IV). The targets were expressed in engine power and gross registered tonnages of fleet 
segments. In order to remove excess capacity from fisheries, the EU established a system of economic incentives co-funded by Member States for vessel decommissioning and effort reduction (Guyader and Daurès 2000; Guyader et al. 2004). However, the exact role of these vessel decommissioning schemes to the reduction of the size of the large French trawlers fleet investigated in this study is largely unknown. The MAGP was abandoned in 2004.

The actual French quota values used as inputs to our BEM are shown in Table 2, and are cumulated across areas where appropriate. Note that blue ling, roundnose grenadier and black scabbardfish have been managed by catch quotas since 2003 , and deepwater sharks since 2005 only. Saithe has been managed by catch quotas over the entire period 19992008. In France, the French Directorate for Sea Fisheries and Aquaculture vests authority for distributing annually national quotas to Producers Organisations (POs). However, the POs quota share at the end of the year may differ from that agreed at the start of the year. This reflects transfers of fishing vessels and/or quotas from one PO to another throughout the year (Marchal 2006). POs then have considerable discretion in allocating their quota share to fishing vessels. However, that process results from an internal strategy, and it is not directly visible from the public domain. Overall, we have a very limited visibility on the process of allocating national quotas to fishing fleets and vessels. In this study, the French quota set for the different species under consideration will therefore be considered as a simple cap put on the total catch.

\subsection{Methods}

\subsubsection{Modeling platform}

Our BEM was developed within the spatially- and seasonally-explicit ISIS-Fish fisheries modeling platform (Mahévas and Pelletier 2004; Pelletier and Mahévas 2005). This platform consists of an interface linked to standard (but flexible) age-structured survival and exploitation equations. This is here referred to as the base model. We have developed other sub-models, using the Java language, which we subsequently coupled with the base model, to describe the dynamics of fishing effort and profit in time and space. The different processes modeled are presented below.

\subsubsection{Population dynamics}

The base ISIS-Fish model equations have been used to describe the age-structured population dynamics of blue ling and saithe, and we summarize the key processes below. The equations are more fully detailed in Mahévas and Pelletier (2004). During each month $k$, the chronology of the processes affecting a population is the following: changing age group, migration, reproduction, recruitment and, fishing and natural mortalities. Processes are assumed to occur instantaneously at the beginning of each month, except fishing and natural mortalities that take place during the whole month after instantaneous processes. In this study, fish recruit and change age group in the $1^{\text {st }}$ January of each year $y$, and blue ling is subject to spawning migrations (see section on model parameterization). Fish are counted at the beginning of each month, and the stock abundance $N$ of species stock $s$, in age group a ( $p$ being the plus group), in year $y$ and month $k$ may be described by equations (1a) and (1b): 


$$
\left\{\begin{array}{l}
N_{\mathrm{s}, \mathbf{y}, k=1, a=1}=R_{\mathrm{s}, y} \\
\cdots \\
N_{\mathrm{s}, \mathbf{y}, k=1,1<a<p}=N_{\mathrm{s}, \mathbf{y} \mathbf{- 1}, k=12, \mathbf{a}-\mathbf{1}} \times \exp \left(-F_{\mathrm{s}, \mathbf{y}-\mathbf{1}, k=12, \mathbf{a}-\mathbf{1}}-\frac{M_{\mathbf{s}}}{12}\right) \\
\cdots \\
N_{\mathrm{s}, \mathbf{y}, k=1, a=p}=N_{\mathrm{s}, \mathbf{y}-1, k=12, p-\mathbf{1}} \times \exp \left(-F_{\mathrm{s}, \mathbf{y}-\mathbf{1}, k=12, \mathbf{a}-\mathbf{1}}-\frac{M_{\mathrm{s}}}{12}\right)+N_{\mathrm{s}, \mathbf{y}-1, k=12, p} \times \exp \left(-F_{\mathrm{s}, \mathbf{y}-\mathbf{1}, k=12, \mathbf{a}-\mathbf{1}}-\frac{M_{\mathrm{s}}}{12}\right)
\end{array}\right.
$$

and

$$
N_{\mathrm{s}, \mathrm{y}, k>1, \mathrm{a}}=N_{\mathrm{s}, \mathrm{y}, k-1, \mathbf{a}} \times \exp \left(-F_{\mathrm{s}, \mathbf{y}, k-1, \mathbf{a}}-\frac{M_{\mathrm{s}}}{12}\right)
$$

where $R$ is recruitment, $M$ the year- and age-invariant natural mortality, $F$ is the annual and monthly fishing mortality at age.

The spawning stock biomass $B$ of species stock $s$, in year $y$ and month $k$ is given by

$$
B_{s, y, k}=\sum_{a=1}^{p} B_{s, y, k, a}=\sum_{a=1}^{p} w a_{s, a} \times m o_{s, a} \times N_{s, y, k, a}
$$

where wa, mo and $N$ represent respectively the weights and maturity ogive at age.

A Schaefer production model has been implemented in the ISIS-Fish modeling platform to forecast the biomass dynamics of the non age-structured stocks: roundnose grenadier, black scabbardfish and deepwater sharks:

$$
\left\{\begin{array}{l}
B_{s, y, k=1}=B_{s, y-1, k=12}+\left(\frac{r_{s}}{12}\right) \times B_{s, y-1, k=12} \times\left(1-\frac{B_{s, y-1, k=12}}{K_{s}}\right)-\operatorname{tot} Y_{s, y-1, k=12} \\
B_{s, y, k>1}=B_{s, y, k-1}+\left(\frac{r_{s}}{12}\right) \times B_{s, y, k-1} \times\left(1-\frac{B_{s, y, k-1}}{K_{s}}\right)-\operatorname{tot} Y_{s, y, k-1}
\end{array}\right.
$$

where $r$ and $K$ are respectively the annual growth rate and the carrying capacity of species $s$, and tot $Y$ is the total yield of species $s$, in year $y$ and month $k$. 


\subsubsection{Yield dynamics}

The ISIS-Fish modeling platform was used to model the yield dynamics of the two French fleets. Different equations were used to represent the dynamics of the age-structured and non age-structured stocks.

Consider age-structured stocks. For the French fleets, the partial fishing mortality $(\varphi)$ of species $s$ (either blue ling or saithe), belonging to age group $a$, in year $y$ and month $k$, which can be attributed to fleet $f$ operating métier $m$, is formulated as

$\varphi_{s, y, k, f, m, a}=q_{s, f} \times v_{y, f} \times S_{s, a} \times T_{s, f, m} \times V_{s, k} \times \rho_{s, m} \times E_{y, k, f, m}$

where $E_{y, k, f, m}$ is the amount of fishing effort (hours fishing) by fleet $f$, operating métier $m$, in year $y$ and month $k ; \rho_{s, m}$ is the proportion of the area occupied by métier $m$ that is intersected by the distribution area of species $s ; V_{s, k}$ is a seasonal factor that quantifies the vulnerability of species $s$ in month $k ; T_{s, f, m}$ is a targeting factor that quantifies how strongly fleet $f$ operating métier $m$ targets species $s ; S_{s, a}$ is the exploitation pattern of species $s$ at age a, which reflects how the different age groups are impacted by fishing; $v_{y, f}$ is the annual harvest efficiency applicable to fleet $f$; and $q$ is a fleet- and species-dependent scaling factor.

Fishing effort $E_{y, k, f, m}$ may be further disaggregated in three components

$E_{y, k, f, m}=W_{y, f} \times \Lambda_{f} \times \theta_{y, k, f, m}$

where $\Lambda_{f}$ is the average number of hours fishing per vessel belonging to fleet $f$, and $W_{y, f}$ is the number of vessels in year $y$ for that fleet, and $\theta_{y, k, f, m}$ is the proportion of the total fishing effort operated by fleet $f$ that has been allocated to métier $m$.

The total monthly fishing mortality at age $(F)$ is then the sum of the partial fishing mortalities $(\varphi)$ from the French fleets and métiers expressed in equation (4), and of the non-French fleet annual partial fishing mortality $(\psi)$, which is here provided as an exogenous process. $F$ is formulated as

$$
F_{s, y, k, a}=\sum_{f} \sum_{m} \varphi_{s, y, k, f, m, a}+\psi_{s, y, a} / 12
$$

The yield $Y$ of stock $s$ by any of the French fleets $f$, operating métier $m$, in year $y$ and month $k$ is (Beverton and Holt 1957)

$$
Y_{s, y, k, f, m}=\sum_{a} \frac{\varphi_{s, y, k, f, m, a}}{F_{s, y, k, a}+M_{s} / 12} \times\left(1-\exp \left(-F_{s, y, k, a}-M_{s} / 12\right)\right) \times B_{s, y, k, f, m, a}
$$


Consider non age-structured stocks. For both French fleets, the partial harvest rate $(h)$ of species $s$ (either roundnose grenadier, black scabbardfish or deepwater sharks), in year $y$ and month $k$, which can be attributed to fleet $f$ operating métier $m$, is formulated as

$h_{s, y, k, f, m}=q_{s, f} \times v_{y, f} \times T_{s, f, m} \times V_{s, k} \times \rho_{s, m} \times E_{y, k, f, m}$

The partial harvest rate equation (8) is equivalent to the age-structured partial fishing mortality equation (4), with subscript a removed and $S$ set to 1 . Fishing effort $E$ is modelled as in equation (5). Note that we could not derive the partial harvest rate for the non-French fleet, using equation (8), since only annual landings were available for that fleet.

A conventional approach of calculating yield $Y$ achieved by the French fleets fishing non agestructured stocks would then be to multiply harvest rate $h$ with current biomass $B$, so catch in any one year and any one month would be a linear function of fishing effort (Schaefer 1954). However, there are two critical corollaries of this assumption. First, catch could indefinitely increase with fishing effort at the same rate, and would exceed biomass at some high effort level. Alternative catch models have been proposed to deal with this issue, and we retained the formulation from Coppola and Pascoe (1998). With this model, catch is non-linearly increasing with fishing effort, and reaches an asymptote, corresponding to the available biomass, as fishing effort tends to the infinity. The second issue to be addressed is that, even if their respective effort tended to the infinity, the total catches from both French fleets should necessarily be lower than the biomass available at the start of the month, because of the yield achieved by the non-French fleet. In order to accommodate the non-French fleet catches in our model, we assumed the following three-step sequence. To start with, we assumed that the non-French fleet $(f=n f r)$ would operate before the two French fleets at the beginning of each month, thereby catching 1/12 of their annual yield $Y_{s, y, f=n f r}$ (estimated from data). That quantity would then be withdrawn from the biomass generated by equation (3). Finally, both the large French trawlers $(f=f r 1)$ and the other French fleet $(f=f r 2)$ would fish on the remaining biomass $\left(B_{s, y, k}-Y_{s, y, f=n f r} 12\right)$. We formulate the yield for non-age structured stocks, partitioned into the two French fleets and métiers, as

$$
\begin{aligned}
& Y_{s, y, k, f, m}=\frac{h_{s, y, k, f \in\{f r 1, f r 2\}, m}}{h_{s, y, k, f=f r 1, m}+h_{s, y, k, f=f r 2, m}}\left(1-\exp \left(-h_{s, y, k, f=f r 1, m}-h_{s, y, k, f=f r 2, m}\right)\right) \\
& \times\left(B_{s, y, k}-Y_{s, y, f=n f r} / 12\right)
\end{aligned}
$$

\subsubsection{Fleet dynamics}

We modelled here economic profit and three major fleet dynamics processes for the large French trawlers: fleet size (through variable $W$ in equation (5)), effort allocation (through variable $\theta$ in equation (5)), and harvest efficiency (through variable $v$ in equations (4) and (8)). For the other French fleet, fleet size and effort allocation were exogenously input in our model using the 1999-2008 observations, while harvest efficiency was assumed constant over the period investigated. The profit achieved by the other French fleet was not calculated since it was to a large extent driven by species not included in our model. The large French 
trawlers" profit and fleet dynamics equations are presented below. We removed the subscript $f$ to simplify subsequent fleet dynamics equations, since they all apply to large French trawlers.

The annual and monthly profit $\Pi_{y, k, m}$ achieved by large French trawlers operating métier $m$ is expressed by

$\Pi_{y, k, m}=\frac{\sum_{s} p_{s, y} Y_{s, y, k, m}}{1-\mu_{y}}-\chi_{y} E_{y, k, m}$

where $p$ and $\chi$ represent the mean annual landing price per unit yield $(€ / \mathrm{kg})$ and operating costs per unit effort ( $€$ /hour fishing) respectively. $\mu$ is the proportion of the gross revenue derived from species other than those considered in the study. We also use in subsequent paragraphs the notation $\Pi_{y}$ for the annual profit achieved by large French trawlers, obtained by summing $\Pi_{y, k, m}$ over all months and métiers.

Fleet size was modeled using a simplification of the original equation relating fleet capacity to past profits (Clark 1990), adapted by Hoff and Frost (2008). This simplification was necessary given the paucity and the aggregated nature of economic information available on large French trawlers. It was in particular not possible to estimate all the economic parameters found in Hoff and Frost (2008), and these were gathered into one single fleetdependent metric $(\delta)$ thereafter. We also assumed that fleet size was constant within a calendar year but could be subject to inter-annual changes as a result of past profits. The number of hours fishing per vessel is assumed constant throughout the simulation period. Any change in the number of hours fishing per vessel would then be reflected in our BEM by a change in the number of vessels (equation (5)). The number of large French trawlers in year $y$ is formulated as

$W_{y}=W_{y-1}+\delta \times\left(\frac{1}{1+u} \sum_{i=0}^{u} \Pi_{y-1-i}\right)$

where $\delta$ is a regression coefficient and $1+u$ is the number of years over which past profits affect fleet capacity changes in equation (11). Compared to the model proposed by Hoff and Frost (2008), we proceeded with three simplifications, to accommodate the limited economic information available to this study. First, Hoff and Frost (2008) parameterized differently situations where fleet size was increasing or decreasing as a result of positive or negative past profits. In other words, a different $\delta$ would in principle be used depending on whether the term in bracket in equation (11) was positive or negative. Here, we used the same $\delta$ to deal in theory with both situations. In practice, however, we could only model an exit situation from the data we had (fleet size decreased monotonically over time), which supports the use of only one parameter in equation (11). Second what we represented by one fleet-dependent variable $(\delta)$ was treated by Hoff and Frost (2008) as a combination of several fleet-dependent economic inputs (e.g., prices per unit capacity of investments/disinvestments, shares of 
profits used for investments/disinvestments in capacity, interest rate, expected lifetime of a vessel). Finally, we assumed that the decision to invest/disinvest was immediate.

Effort allocation was modelled similarly to Marchal et al. (2011). We considered that a single fleet might operate different métiers, the choice of which is a combination of economic opportunities and tradition. The proportion of effort allocated to a métier then depends dynamically on two quantities. The first quantity is linked to the anticipated profit for the métier being considered, which is here derived from the actual monthly profit observed in the previous year. We used, however, a more flexible formulation compared to that suggested by Marchal et al. (2011), by making the following changes. First we used as economic driver the anticipated profit per unit of effort instead of the plain anticipated profit, so fishers may choose their métier on the basis of what one unit of effort could really produce. Then, we assumed that fishers would avoid targeting species the quota of which is attained. Finally, we derived the exponential of anticipated profit per unit of effort to circumvent some of the necessary assumptions (e.g., fishing suspension) Marchal et al. (2011) had to make wherever the anticipated monthly profit was negative for some métiers. The second quantity is the traditional effort allocation for the fleet, which is here derived from the model estimated values during the same month in the previous year (Marchal et al. 2011). The relative weight given to anticipated profit and traditions is defined by a parameter $\alpha$, the effort allocation coefficient that we varied. The proportion of fishing effort $(\theta)$ allocated to métier $m$ is formulated as

$$
\theta_{y, k, m}=\alpha\left[\frac{\exp \left(\frac{\Pi_{y-1, k, m}-\sum_{s} \lambda_{s, y, k, m} Y_{s, y-1, k, m}}{E_{y-1, k, m}}\right)}{\sum_{m} \exp \left(\frac{\Pi_{y-1, k, m}-\sum_{s} \lambda_{s, y, k, m} Y_{s, y-1, k, m}}{E_{y-1, k, m}}\right)}\right]+(1-\alpha)\left[\frac{E_{y-1, k, m}}{\sum_{m} E_{y-1, k, m}}\right]
$$

where $\lambda_{s, y, k, m}=0$ if the quota of species $s$ in year $y$, month $k$, and in the fishing area operated by métier $m$ is not exceeded, and $\lambda_{s, y, k, m}=p_{s, y}$ otherwise. When the quota of a given species is reached, the fleets do not expect an economic return from selling it, and therefore are incentivized to operate métiers with reduced by-catch of this species.

Harvest efficiency $(v)$ was the last fleet dynamics process built in our model. Increases in harvest efficiency may have happened over the simulated period as a result of technological enhancements in both fishing vessels and gears, but also through changes in the fleets" composition towards more efficient vessels. We assumed that increases in harvest efficiency happened through a constant annual rate $\beta$, that we varied in this study. $\beta$ is referred to as the "harvest efficiency coefficient" hereafter. Annual harvest efficiency $v$ is then formulated as

$$
\left\{\begin{array}{l}
v_{0}=1 \\
v_{y}=(1+\beta) v_{y-1}
\end{array}\right.
$$




\subsection{Model parameterization}

\subsubsection{Populations dynamics}

We have used the inputs (weights at age, maturity ogive, natural mortality) and some of the outputs (recruitment estimated over 1999-2008, abundance numbers at age in 1999) from the blue ling and saithe stock assessments (as shown in Table 1) to parameterize the dynamics of these stocks in the BEM. Recruitment was assumed to occur in January for both stocks. Blue ling and saithe exploitation patterns (fishing mortality at age relative to fishing mortality averaged over age groups) were annual inputs to the BEM for each year (Table 1). We have used the Schaefer model parameters and the 1999 biomass estimates to mimic the dynamics of roundnose grenadier, black scabbardfish and deepwater sharks in the BEM (Table 3). For these three stocks, growth was applied with a constant rate $(r / 12)$ over all months.

The spatial grid used to map the different distribution areas was made up of ICES rectanglebased dimensioned cells. Based on Large et al. (2010), we estimated that blue ling spawning areas occupied on average $9 \%$ of the total population distribution area. We assumed here that in the non-spawning season (from June to February), all blue ling age groups were uniformly distributed over the total distribution area (i.e. $91 \%$ in the non spawning area and $9 \%$ in the spawning area). We assumed that fish move instantaneously into the spawning areas in March, from where $91 \%$ return to the non-spawning areas in the beginning of June. All the other stocks were assumed uniformly distributed over their respective distribution area.

Post-recruited stock abundance at age (blue ling and saithe) and total biomass (roundnose grenadier, black scabbardfish, deepwater sharks) were then endogenously modelled annually and monthly from February 1999 to December 2008.

\subsubsection{Yield dynamics}

Of the three fleets considered in this study, detailed yield process information was only available for the two French fleets. Equations (1-6) and (8) where therefore calibrated for these two fleets, using external information (i.e., $\psi$ for age-structured stocks and $Y_{s, y, f=n f r}$ for non age-structured stocks), as explained below.

The exploitation pattern $S$ of blue ling and saithe was calculated as the ratio between fishing mortality $(F)$ at age (as output from stock assessment) and the mean $F$ averaged over all age groups (Table 1). Both French fleets were assumed to have the same exploitation pattern for these species. For all species, $\rho$ was calculated as the proportion of each métier area that was occupied by the species under consideration. The targeting factor $(T)$ and the vulnerability $(V)$ were estimated by modelling the CPUE of each species via a stepwise deltaGLM (Maunder and Punt 2004) over the period 1999-2008. First, the probability of presence of a species in the catch was modelled using the binomial distribution. Second non-zero CPUE was modelled using a log-normal distribution. In both steps, the explanatory variables were a year effect and an interaction term between the (two) fleets and the (ten) métiers. An additional seasonal effect was added for blue ling with two classes: spawning (from March to May) and not spawning (from June to February) to reflect different targeting levels by fishers throughout the year. The targeting factor $(T)$ was set for all species to the effect of the interaction between fleets and metiers, as derived from the delta-GLM. The targeting factor should be interpreted as the average species CPUE produced by one fleet operating a given métier, and the values input in our model are shown in Table 5 . Blue ling vulnerability $(V)$ was set to the seasonal effect derived from the delta-GLM. $V$ was set to 1 for all other species. In 1999, $v$ was initialised to 1 , while the number of vessels $\left(W_{1999, f}\right)$, the average 
number of hours fishing per vessel $\left(\Lambda_{f}\right)$, the monthly proportion of effort allocated to the different métiers $\left(\theta_{1999, k, f, m}\right)$, and the resulting fishing effort $\left(E_{1999, k, f, m}\right)$ were derived from observed values (Tables 4 and 5). The scaling factor $q$ of age-structured species (blue ling and saithe) was calibrated for each fleet by scaling the partial fishing mortality derived from equation (4) to the actual 1999 fishing mortality estimates apportioned to the catches of the two fleets. The same procedure was applied to calculate $q$ for non age-structured species (roundnose grenadier, black scabbardfish and deepwater sharks), by scaling the partial harvest rate derived from equation (8).

Yield dynamics from the non-French fleet were exogenous to our model, and these were included, either as an annual partial fishing mortality $(\psi)$ for age-structured stocks in equation (6), or more directly as an annual yield $\left(Y_{s, y, f=n f r}\right)$ for non age-structured stocks in equation (9). Table 2 shows for all stocks the proportion of the total international catch that is taken by the three fleets being investigated. $\psi$ was calculated every year by partitioning the annual total fishing mortality estimated from stock assessments according to the relative contribution of the non-French catches to the international catches given in ICES (2011a,b). In the absence of available seasonal data, we assumed that the non-French fleet"s annual fishing mortality (of blue ling and saithe) or yield (of roundnose grenadier, black scabbardfish and deepwater sharks) was evenly distributed in each month throughout the year. The blue ling and the saithe exploitation patterns of the non-French fleet were assumed the same as for the French fleets (Table 1).

Provided the monthly dynamics of fishing effort of the two French fleets are reproduced over 2000-2008 (as explained below), fishing mortality and catches may now be modelled over the whole time period.

\subsubsection{Fleet dynamics}

The large French trawlers fleet is the main contributor to deepwater fishing off the Western British Isles, and its landings are mostly composed of the species being investigated in this study. As a result, most of the dynamics of this fleet have been endogenously modeled and subsequently simulated through equations $(10-13)$. The species landing price (Table 2$)$, the proportion in gross revenue of species other than those investigated in this study and operating costs (Table 4), were used to parameterize $p, \mu$ and $\chi$ respectively in the fishing profit equation (10), over the whole period 1999-2008. From the data we had, it was not possible to distinguish between travelling and fishing time/costs. $\chi$ was therefore derived by dividing total annual operating costs by the annual number of fishing hours observed over 1999-2008. Therefore, travelling costs were included in $\chi$. In the absence of disaggregated information, we assumed that operating costs were invariant within year, across métiers and species targeted. In equation (11), $\delta$ was estimated for the large French trawlers as the slope of the regression between actual inter-annual change in fleet size and average past profits. There were ten years of economic data available (1999-2008). However, due to the lagged nature of the fleet size model, the regression could only be conducted with $9-u$ years. Therefore, we could not realistically explore values of $u$ larger than 1 , since increasing $u$ mechanically reduces the amount of years used to estimate $\delta$. Two $u$ values ( 0 and 1$)$ were then explored. The best goodness of fit, based on the R-squared criterion, was achieved with $u=1$, meaning that the difference in fleet size was best linearly related to profits in the past two years. This also means that $W_{1999}$ and $W_{2000}$ were necessarily input to the BEM, while $W_{y>2000}$ was endogenously modeled. Finally, we estimated a regression equation between the interannual change in fleet size and the average past two profits $\left[W_{y}-W_{y-1}=7.283 \times 10^{-8} \times\left(0.5 \times \Pi_{y-1}\right.\right.$ $\left.\left.+0.5 \times \Pi_{y-2}\right) ; R^{2}=0.87\right]$, the slope of which $\left(\delta=7.283 \times 10^{-8}\right)$ was significant $(\mathrm{p}<0.0001)$. 
The size of the large French trawlers fleet was reduced from 25 to 13 vessels over the period 1999-2008. Such a structural change in the fleet composition could have affected harvest efficiency through decommissioning of the less efficient vessels. In order to evaluate whether such a reduction in the number of large French trawlers could have affected the overall harvest efficiency of that fleet, we conducted a GLM analysis of the log-transformed value per unit effort (VPUE) by fishing trip and by vessel over the period 1999-2008. The VPUE was calculated by weighting the CPUE of blue ling, saithe, roundnose grenadier, black scabbardfish and deepwater sharks by their respective landing prices. The link function was identity. The explanatory variables were a combination of métiers and months, a year effect, and a "fisheries exit" binary variable. The "fisheries exit" variable discriminated those fishing vessels present in the fishery in 1999 that left the fishery before 2008, and those which were still active in 2008. All the explanatory variables were significant $(p<0.0001)$. The analysis suggested that the VPUE of the fishing vessels present in the fishery in 2008 was on average $27 \%$ higher than those vessels that left the fishery before 2008 . Note that although GLM have proven to be a valuable tool for the analysis of fisheries data (Gavaris 1980; Hilborn 1985; Brynjarsdottir and Stefansson 2004), more complex approaches could also have been considered to accommodate, (1) auto-correlations (Generalised Estimation Equations - GEE) (Bishop et al. 2004; Zurr et al. 2009), (2) unbalanced catch and effort datasets (Generalized Linear Mixed Models - GLMM) or, (3) non-linear effects of explanatory variables (Generalized Additive Models) (Maunder and Punt 2004).

In equation (12), the effort allocation coefficient $\alpha$ was gradually varied between 0 (no change in effort allocation) to 1 (totally economically-driven effort allocation), by $1 / 100$ increments (between 0.0 and 0.1 ), and then by $1 / 10$ increments (between 0.1 and 1.0). French quotas were needed to derive $\lambda$, and these have been provided for all species under consideration. Note that in the no-TAC period (e.g., before 2003 for most deepwater species), $\lambda$ was accordingly set to 0 for the unregulated species. Finally, the harvest efficiency coefficient $\beta$ was varied gradually from 0 to $20 \%$ per year, by $2 \%$ increments. All in all, 220 combinations of $\alpha$ and $\beta$ have been simulated in this study.

Because the dynamics of the other French fleet are mainly determined by species other than those modeled here, they could not be endogenously built in our model through equations $(10-13)$. Both the number of vessels and the proportion of effort allotted to each métier for that fleet were input exogenously to the BEM over the period 1999-2008, while harvest efficiency was assumed constant (Table 4).

We summarize in Table 6 those processes that are endogenously and dynamically modelled, and those which are exogenously supplied, into our BEM.

\subsection{Model performance}

Different runs of the BEM were carried out with different values of $\alpha$ and $\beta$. For each run, we calculated the residuals sum of squares, $\operatorname{RSSQ}(\alpha, \beta)$, as an indicator of the model fitness to the 1999-2008 observations. We then evaluated the extent to which accounting for fleet dynamics could improve the performance of fisheries forecast by comparing the residuals sum of squares derived from a "no fleet dynamics" model where both $\alpha$ and $\beta$ were set to zero (i.e., no increase in harvest efficiency and no change in effort allocation over time), RSSQ $(\alpha=0, \beta=0)$, with the residual sum of squares resulting from different models building in fleet dynamics by varying both $\alpha$ and $\beta$, RSSQ $(\alpha>0, \beta>0)$.

A "fleet dynamics value-added index" (FDVAI) was then calculated for different values of $\alpha$ and $\beta$, as the ratio between RSSQ $(\alpha>0, \beta>0)$ and RSSQ $(\alpha=0, \beta=0)$. When FDVAI is lower than 1 , including fleet dynamics improves the precision of the model forecast, and the 
lower the better. By contrast, building in fleet dynamics does not bring any added value to the model when FDVAl is greater than 1. The FDVAI was calculated separately for annual catch, fishing effort and profit. The FDVAI was also derived for two aggregation levels of these variables: (1) by year, summed over months and métiers and, (2) by year, month and métier. Finally, model residuals were plotted against predicted values and then tested for normality (QQ plot).

\section{Results}

We first tested the ability of our model to forecast, for the large French trawlers, the total annual catches by species, fishing effort, and profit, based on the value taken by the FDVAI index (Figures 1 and 2). Values of FDVAl greater than 2 (representing $22 \%, 26 \%$ and $27 \%$ of the FDVAl values derived for annual catches, effort and profit respectively) are not shown. The FDVAl calculated for blue ling catches (Figure 1a), saithe catches (Figure 1b), roundnose grenadier (Figure 1c), deepwater sharks catches (Figure 1e), fishing effort (Figure $2 a$ ) and profit (Figure $2 b$ ) was lower than 1 (i.e., model forecast were improved with fleet dynamics built in) for all these variables simultaneously, wherever the harvest efficiency coefficient was in the range $2-8 \%$ per year. The lowest FDVAI was found with a harvest efficiency coefficient of 6-8\% per year, except for black scabbardfish catches, where a substantially higher value was found for the harvest efficiency optimum (14\% per year, Figure 1d). The FDVAI of the different annual series was in general less sensitive to the effort allocation coefficient. A minimum FDVAI was achieved with $\alpha$ in the range 0.1-0.4, in relation to the catches of blue ling, saithe, roundnose grenadier and deepwater sharks. Increasing the effort allocation coefficient above 0 did not enhance black scabbardfish catch forecast. The effort allocation coefficient had a non-monotonic effect on the precision of annual fishing effort and profit, and that effect was in any case very limited compared to that of the harvest efficiency coefficient (Figure 2). When the harvest efficiency and the effort allocation coefficients are set at $8 \%$ per year and 0.2 respectively, FDVAl is in the range $0.2-$ 0.8 (i.e., the RSSQ obtained with the built-in fleet dynamics model are reduced by $20-80 \%$ compared to the "no fleet dynamics" model RSSQ) for all variables considered. Within this range of values, model residuals were little correlated to predicted values, and inspection of the $Q Q$ plots indicated that their distribution was close to normal.

We then tested the ability of our model to forecast, for the large French trawlers, annual and monthly species catches and fishing effort by métier (Figure 3), based on the FDVAI value. Values of FDVAI greater than 2 are not represented. The lowest FDVAI for blue ling catches (Figure 3a), saithe catches (Figure 3b), roundnose grenadier catches (Figure 3c), deepwater sharks catches (Figure 3d) and fishing effort (Figure 3f) were found with a harvest efficiency increase of $4-10 \%$ per year. A substantially higher harvest efficiency optimum (14\% per year) was found for black scabbardfish catches. The FDVAl was also sensitive to the effort allocation coefficient, with an optimum value in the range 0.1-0.3 for all variables considered except for black scabbardfish catches. Increasing the effort allocation coefficient above 0 did not enhance black scabbardfish catch forecast. When the harvest efficiency and the effort allocation coefficients are set at $8 \%$ per year and 0.2 respectively, FDVAl is in the range $0.4-$ 1.0 (i.e., the RSSQ obtained with the built-in fleet dynamics model are reduced by $0-60 \%$ compared to the "no fleet dynamics" model RSSQ) for all variables considered.

To illustrate the simulated fishers" decision-making process, we show in Figure 4 the monthly ratio between realized and anticipated relative profits by métier, and also the monthly ratio between current and previous year relative fishing effort per métier, averaged over the simulated period, when the harvest efficiency and the effort allocation coefficients were set at $8 \%$ per year and 0.2 respectively. These monthly ratios are generally close to 1 , with some variations from one métier to another. Still, the relative realized profits are slightly lower than 
the anticipated ones for all metiers except that targeting saithe ("Dem4"). We can also see that only métier "Dem4" becomes slightly more attractive (inter-annual changes in relative fishing effort larger than 1). The relative fishing effort of all other metiers is on average slightly decreasing, or is unchanged, over the simulated period.

Finally, we examined the yearly and monthly time series of the different model"s outputs, with the effort allocation coefficient set at 0.2, and with increases in harvest efficiency of 4,8 and $12 \%$ per year. These values were selected since they are in the neighbourhood of the area where FDVAI was minimal for the different variables considered (Figures 1-3).

Figure 5a indicates that annual fishing effort operated by large French trawlers was well forecast with an increase in harvest efficiency of $8 \%$ per year. The forecast of the detailed yearly and monthly fishing effort by métier was more variable. In general, the forecast was reasonable for all métiers over the period 1999-2003, and was only slightly sensitive to the harvest efficiency coefficient during this period (Figures 5b-f). Between 2004 and 2008, however, the BEM generally under-estimated the fishing effort allocated to the most important deepwater métiers DeepEdge6 (Figure 5b), DeepOther6 (Figure 5c) and DeepRef5 (Figure 5d). By contrast, the model over-estimated the fishing effort allocated to the demersal métier Dem4 (Figure $5 \mathrm{e}$ ) and to all the remaining lesser important métiers (Dem5, Dem6, Dem78, DeepNew5, DeepNew6, DeepRef7) that we binned into one single "Various" category (Figure 5f). The best fits for métiers DeepRef5 and Dem4 were achieved with contrasted harvest efficiency coefficients of $12 \%$ and $4 \%$ per year respectively. The model could not fit satisfactorily the 2004-2008 fishing effort observations for métiers DeepOther6 and "various", irrespective of the values taken by the harvest efficiency coefficient.

The large French trawlers" annual total profit (Figure 6a), as well as their annual and monthly catches of blue ling (Figure 6b), saithe (Figure 6c), roundnose grenadier (Figure 6d) and deepwater sharks (Figure 6f) forecast by the model fitted the observations satisfactorily, overall, with an increase in harvest efficiency of $8 \%$ per year. The BEM consistently underestimated black scabbardfish catches, irrespective of the harvest efficiency coefficient, over the whole period 1999-2008 (Figure 6e).

These results were generally confirmed by the inspection of residuals. When the harvest efficiency and the effort allocation coefficients were set at $6-8 \%$ per year and 0.2 respectively, annual total fishing effort and profits residuals were little correlated to predicted values, and inspection of the $Q Q$ plots indicated that their distribution was close to normal. No strong residual patterns were generally observed when fishing effort and catches were examined at the métier and/or species level over the period 1999-2004, except for black scabbardfish catches. However, over the period 2005-2008, residuals of effort and catch per métier and/or species were generally correlated with predicted values, and not centred on 0 .

\section{Discussion}

The results of this study indicate that accounting for two key fleet dynamics elements, harvest efficiency and effort allocation, may improve substantially the credibility of catch and effort forecast by métier over a ten-year period. The best overall fit was achieved where effort allocation was determined $80 \%$ by tradition and $20 \%$ by economic opportunism, and where harvest efficiency increased by around $8 \%$ a year.

The higher weight given to tradition relative to economic opportunism is consistent with that estimated in previous discrete-choice modelling studies applied to a variety of fisheries 
worldwide (Holland and Sutinen 1999; Hutton et al. 2004; Marchal et al. 2009a). The strong adherence towards previously operated métiers probably reflects seasonal patterns in harvested species life cycle and weather conditions, but also conversion costs required to target other species (Bockstael and Opaluch 1983; Pradhan and Leung 2004; Andersen et al. 2012). Eventually, traditions incorporate fishers" experience and ability to timely fish on appropriate fish aggregation, and in a profitable way. Therefore, what we refer to as traditions may overlap to some extent with economic opportunism, and may explain the high weight allotted to past habits in many discrete-choice modelling investigations, including this study.

The annual increase in harvest efficiency estimated confirms the outcomes of earlier studies, suggesting that increasing trends in fishing power have been a familiar ingredient of EU fisheries in the past decades (Pascoe and Robinson 1996; Millischer et al. 1998; Kirkley et al. 2004). The estimated harvest efficiency increase of $8 \%$ per year is large (Fitzpatrick 1996; Kirkley et al. 2004; Hannesson 2007), but it is in the range of what has been found in different studies investigating trawlers" fishing power worldwide (Robins et al. 1998; Mahévas et al. 2004). However, discussions with vessel owners suggested that the technology of the large French trawlers in activity has been subject to little changes over the period investigated. Therefore, the $8 \%$ annual increase in harvest efficiency is probably too high to be explained only by some technological enhancement in the individual vessels" gears and on-board equipment (technological creep).

Another mechanism that could explain the estimated annual trend in harvest efficiency is decommissioning of the less efficient vessels. The size of the large French trawlers fleet has been reduced from 25 to 13 vessels over the period 1999-2008, and we showed here that the VPUE of the fishing vessels present in the fishery in 2008 was on average $27 \%$ higher than those vessels that left the fishery before 2008. This result is a preliminary confirmation that the change of fleet composition observed over the period 1999-2008 has overall resulted in a substantial increase of the large French trawlers" harvest efficiency, which supports the outcomes of this study.

An alternative approach to simulating a range of harvest efficiency coefficients to get the best model"s fit would have been to derive changes over time of total factor productivity based on some stochastic output-oriented distance (Caves et al. 1982) or transformation (Felthoven and Morrison-Paul 2004) function, and then incorporate the estimated value exogenously in our fishing mortality and harvest equations. Productivity growth estimated from these economic models would then vary from one year to another, and would not be an annual flat rate as in our study. However, productivity growth estimates derived from these models are spatially aggregated, so they could reflect in one metric different fleet dynamics elements, including harvest efficiency, but also spatial changes in fishing effort allocation, while our model discriminates between these two processes. These structural differences would hence make it difficult to input directly the productivity growth estimated by these economic models into the BEM developed in this study.

It is perhaps not so surprising that the total (aggregated over all metiers) annual fishing effort and profit, observed over the period 1999-2008, were well reproduced by the model over the whole time period. This is because the relation between total effort and profit was estimated based on a regression using the same observed fishing effort data than those used to validate the model outcomes. However, our yield dynamics model, which fed in partially the profit equation, was unaware of the 2000-2008 data. This means that predicted profits could potentially deviate from observations if the harvest dynamics model poorly reproduced actual catches. In return, total annual fishing effort, which is linearly related to past profits, would also deviate from observations, eventually. This happened in particular when harvest efficiency did not increase over time, resulting in an underestimation of total annual fishing effort and profit, which was largely corrected when $\beta$ was set around $8 \%$ per year $(60 \%$ and 
$80 \%$ of reduction in the RSSQ for profit and fishing effort respectively), compared to the "no fleet dynamics model" scenario. In any case, the reasonable fit between fleet size and past profits provides an a posteriori confirmation that the simplifications brought about in our fleet size equation were reasonable, and perhaps also that the impact of management measures (MAGP, TAC) that applied to the large French trawlers over the period 1999-2008 were offset by past economic performance.

It is appealing that annual and monthly observed fishing effort and species catches by métier were generally well reproduced by the model over the period 1999-2003, for a broad range of harvest efficiency and effort allocation coefficients, since the fleet dynamics model was only aware of the 1999 data. This suggests that building in key fleet dynamics processes endogenously into BEM improved forecast credibility five years ahead. Beyond the 19992003 period, however, the model allocated too much fishing effort to the North Sea demersal métier "Dem4" (saithe fishing) and to a mix of lower importance demersal and deepwater métiers, and too little fishing effort to the most important traditional deepwater métiers ("DeepEdge6","DeepOther6","Ref5"). While the rationale underlying this effort allocation shift over time is still to be investigated, we may propose two complementary hypotheses to explain it.

First, the issue may not be related to the parameterisation of the effort allocation model itself, but rather to the fact that the model builds in fishers" perception of stock density (through the expected profit function), and that in return stock density is determined by fishing effort. Therefore, any deviation between the true state and the simulated population or fleet dynamics assumed process would propagate and amplify over time. In our case, the fit was reasonable during five years, but not afterwards.

Second, some of the assumptions made around the fleet dynamics model could be at fault. The effort allocation coefficient may not be constant over the whole simulated time period, as it has been assumed to be in this study, consistent with previous fishers" discrete-choice modelling studies (Holland and Sutinen 1999; Hutton et al. 2004; Marchal et al. 2009a). In our case, that coefficient could probably reasonably be set at 0.2 over the period 1999-2003, but not over the period 2004-2008. Whatever the hypothesis retained, it is perhaps noteworthy that the process shift occurred in a period where the catch quota regime established for deepwater species in 2003 became restrictive. That, in combination with decreasing fleet size and increasing fuel prices, could have resulted in a lower attractivity of the métiers operating on the most remote fishing grounds (e.g. métiers Dem4, DeepNew5, and DeepNew6). A step forward could be to develop a more complex fleet dynamics model building on concepts such as the game theory (Trisak 2005), optimal foraging (Bertrand et al. 2005), or advection-diffusion equations (Bertignac et al. 1998; Faugeras and Maury 2007). Such a model could also build in an improved representation of economic opportunism than the previous year profits (equation (12)). For instance, one could consider integrating in our fleet dynamics model other cues such as the fishers" perception on the spatial and temporal fish availability from previous months as a representation of current fish movements. Such approaches, however, would require a larger number of parameters to estimate, which would not be tractable given the data available to this study.

Similarly, we assumed a flat annual increase in harvest efficiency, consistent with many modelling investigations on fishing power (Pope and Shepherd 1985; Ulrich et al. 2002; Bastardie et al. 2010c). However, there are many reasons why the time dynamics of harvest efficiency could be of a more complex nature. Technological development could in principle be an obvious cause of stepwise increases in harvest efficiency (Hannesson 2007; Hannesson et al. 2010; Eigaard et al. 2011). However, as mentioned earlier, large French trawlers were subject to limited technological development over the period 1999-2008. Other complex drivers of harvest efficiency include the competition between fishing vessels (Gillis and Peterman 1998), and also management constraints (Pascoe et al. 2001). In particular, 
the inception of the TAC system for deepwater stocks in 2003 may have resulted in a stepwise change in harvest efficiency, which may also explain why the model"s fit is poor over the period 2004-2008.

Because of the aggregated nature of economic data available to this study, we assumed hereby that operating costs per unit effort of the large French trawlers were constant across métiers (or fishing grounds). Given the structure of our model, this means that the distance covered to reach a fishing ground (and the fuel costs it implies) is not taken into account in the fishers" decision-making process. This assumption would be unrealistic if, e.g., fishers had to choose between fishing in coastal areas or offshore. In our case, however, all fishing grounds are generally offshore and remote relative to French home harbors (see e.g. Holley and Marchal 2004, Fig. 4). Therefore, most of the operating costs were driven by travelling from the home harbor to the fishing grounds, whatever they are, and the cost difference of choosing a fishing ground rather than another was assumed limited compared to that. This assumption could be at fault because some of large French trawlers could land their harvest and resume their fishing trip in more Northern harbors, located in Scotland and Denmark, so to reduce fuel consumption and/or find more attractive landing prices. We did not have sufficient quantitative elements, however, to incorporate that process in our model.

A number of parameters of our model were estimated through stock assessments. We used the ICES stock assessment outputs to parameterise the population and exploitation dynamics of the saithe and roundnose grenadier stocks under investigation (ICES 2011a, b). No such estimates were available for blue ling, black scabbardfish and deepwater sharks. We then carried out preliminary stock assessments to parameterise the population and harvest dynamics of these stocks. It should be noted that the growth rates estimated for black scabbardfish and deepwater sharks were similar (Table 3), while current knowledge on the longevity of these stocks would suggest a lower growth rate for deepwater sharks (ICES $2011 \mathrm{~b}$ ). This is likely due to the large negative correlation between carrying capacity and growth rates estimated from the Schaefer model. Despite the preliminary nature of some of the stock assessments, the annual catch trends of blue ling, saithe, roundnose grenadier and deepwater sharks were overall reasonably well reproduced by the model, except in the last two simulated years. Black scabbardfish catches, however, were consistently underestimated. This mismatch could reflect violation of a key assumption made on black scabbardfish stock structure when assessing this stock. Thus, while ICES has traditionally considered that black scabbardfish in Division Vb and Subareas VI and VII is a distinct stock unit to the other Western European black scabbardfish stock distributed in Subareas VIII and IX, ICES has also at the same time stressed the need to revisit seriously this assumption, based on increased evidence that the Western European black scabbardfish stock is likely distributed over both geographical units (ICES 2011b).

Many key processes have been endogenously modelled (post-recruited biomass and harvest dynamics, fleet size, profit, effort allocation, harvest efficiency). Admittedly, however, a number of equally important processes have been treated as exogenous, due to either a lack of knowledge on the processes involved (recruitment, fish prices, operating costs per unit effort), or insufficient data (dynamics of the other fleets catching the species under consideration, dynamics of the other species not considered in this study but which contributed to the profit achieved by the large French trawlers). Our model did not incorporate possible trophic interactions between the species under consideration. In fact, there is only little quantitative information of prey/predation- or competition-type interactions within the complex of deepwater species in the North-East Atlantic, and none that could be used to parameterise any ecosystem model. Finally, the fleet dynamics structure of this model could be made more complex by building in competition (or possibly cooperation) between fishing fleets, which has been shown to alter effort allocation in previous studies (Gillis and Peterman 1998; Rijnsdorp et al. 2000). 
Despite these limitations, it is perhaps comforting that the total annual catch and effort were overall well reproduced by the model over 1999-2008, and also that forecast by métier were reasonably close to observations over the first five years of the simulated period. The lack of fit of catch and effort by métier 2004-2008 suggests, and this is one lesson which may be drawn from this paper, that evaluating the prediction performance of a complex mixed fisheries BEM should be achieved by comparing model forecast with observations at a finescale, and not only at an overly aggregated level. In its present form, our model is more appropriate to reproduce historical trends and short-term predictions rather than long-term forecasts.

While the results obtained are likely specific to the case study, the framework developed here could in principle be applied to any mixed fishery, for which sufficient biological and economic information is available to parameterise the underlying model. A key step forward will then be to use this model within a management strategy evaluation framework. That would require to integrate in the model those processes that have been here treated as endogenous, either by making the process explicit (e.g., stock-recruitment relationship, harvest control rule, stock assessment, price elasticity function, competition between fishing fleets), or through sensitivity analyses when information is insufficient, and also to build in uncertainty adequately. Such development will be carried out in a companion study.

\section{Acknowledgements}

This work was funded by the EU-FP7 project DEEPFISHMAN project (Grant agreement no. 227390). This support is gratefully acknowledged. We thank Marc Mangel and two anonymous referees for their thoughtful and thorough comments, which improved the manuscript.

\section{References}

Andersen, B.S., Vermard, Y., Ulrich, C., Hutton, T., and Poos, J.-J. 2010. Challenges in integrating short-term behaviour in a mixed-fishery Management Strategy Evaluation framework: A case study of the North Sea flatfish fishery. Fish. Res. 102: 26-40.

Andersen, B.S., Ulrich, C., Eigaard, O.R., and Christensen A.S. 2012. Short-term choice behaviour in a mixed fishery: investigating métier selection in the Danish gillnet fishery. ICES. J. Mar. Sci. 69: 131-143.

Bastardie, F., Nielsen, J.R., and Kraus, G. 2010a. Management Strategy Evaluation Framework for the Eastern Baltic Cod Fishery to Test Robustness of Management Against Environmental Conditions and Fleet Response Scenarios. ICES J. Mar. Sci. 67: 71-86.

Bastardie, F., Nielsen, J.R., Andersen, B.S., and Eigaard, O. 2010b. Effects of fishing effort allocation scenarios on energy efficiency and profitability: an individual-based model applied to Danish fisheries. Fish. Res. 106: 501-516.

Bastardie, F., Vinther, M., Nielsen J.R., Ulrich, C., and Paulsen, M.S. 2010c. Stock-based vs. fleet-based evaluation of the multi-annual management plan for the cod stocks in the Baltic Sea. Fish. Res. 101: 188-202.

Bertignac, M., Lehodey, P., and Hampton, J. 1998. A spatial population dynamics simulation model of tropical tunas using a habitat index based on environmental parameters. Fish. Oceanogr. 7: 326-334.

Bertrand, S., Burgos, J.M., Gerlotto, F., and Atiquipa, J. 2005. Levy trajectories of Peruvian purse-seiners as an indicator of the spatial distribution of anchovy (Engraulis ringens). ICES J. Mar. Sci. 62: 477-482. 
Beverton, R.J.H., and Holt, S.J. 1957. On the dynamics of fish populations. U.K. Ministry of Agriculture Fish and Fisheries Investigations, London, (Ser. 2)19, 533 pp.

Bishop, J., Venables, W.N., and Wang, Y.G. 2004. Analysing commercial catch and effort data from a Penaeid trawl fishery. A comparison of linear models, mixed models, and generalized estimating equations approaches. Fish. Res. 70: 179-193.

Bockstael, N.E., and Opaluch, J.J. 1983. Discrete modeling of supply response under uncertainty: the case of fisheries. Can. J. Mar. Sci. 10: 125-137.

Branch, T.A., Hilborn, R., Haynie, A.C., Fay, G., Flynn, L., Griffiths, J., Marshall, K.N., Randall, J.K., Scheuerell, J.M., Ward, E.J., Young, M. 2006. Fleet dynamics and fishermen behavior: lessons for fisheries managers. Can. J. Fish. Aquat. Sci. 63: 1647-1668.

Brander, K. 2003. What kinds of fish stock predictions do we need and what kinds of information will help us to make better predictions? Sci. Mar. 67: 21-33.

Brynjarsdottir, J., and Stefansson, G. 2004. Analysis of cod catch data from Icelandic groundfish surveys using generalized linear models. Fish. Res. 70: 195-208.

Caves, D.W., Christensen, L.R., and Diewert, W.E. 1982. The economic theory of index numbers and the measurement of input, output, and productivity. Econometrica 50: 1393-1414.

Charuau, A., Dupouy, H., and Lorance, P. 1995. French exploitation of the deep-water fisheries of the North Atlantic. In: Hopper, A. G., Deep-water fisheries of the North Atlantic oceanic slope, 296. Kluwer Academic Publishers, Dordrecht/Boston/London, 337-356.

Clark, C.W. 1980. Towards a predictive model for the economic regulation of commercial fisheries. Can. J. Fish. Aquat. Sci. 37: 1111-1129.

Clark, C.W. 1990. Mathematical Bioeconomics: The Optimal Management of Renewable Resources, Wiley, New York.

Coppola, G., and Pascoe, S. 1998. A surplus production model with a nonlinear catch-effort relationship. Mar. Resour. Econ. 13: 37-50.

Drouineau, H., Mahévas, S., Pelletier, D., and Beliaeff, B. 2006. Assessing the impact of different management options using ISIS-Fish : the French Merluccius merluccius Nephrops norvegicus mixed fishery of the Bay of Biscay. Aquat. Living Resour. 19: 15-29.

EC 2009. Impact Assessment Guidelines. European Commission, SEC(2009) 92, 50 pp. http://ec.europa.eu/governance/impact/commission_guidelines/docs/iag_2009_en.pdf

Ehrich, S., and Reinsch, H.H. 1985. Investigations on the blue ling stock (Molva dypterygia) in the waters west of the British Isles. Arch. Fischereiwiss. 36: 97-113.

Eigaard, O.R., Thomsen, B., Hovgaard, H., Nielsen, A., and Rijnsdorp, A.D. 2011. Fishing power increases from technological development in the Faroe Islands longline fishery. Can. J. Fish. Aquat. Sci. 68: 1970-1982.

Faugeras, B., and Maury, O. 2007. Modeling fish population movements: from an individualbased representation to an advection-diffusion equation. J. Theor. Biol. 247: 837-848.

Felthoven, R.G., and Morrison-Paul, C.J. 2004. Multi-output, nonfrontier primal measures of capacity and capacity utilization. Am. J. of Agr. Econ. 86: 619-633.

Fitzpatrick, J. 1996. Technology and Fisheries Legislation, In Precautionary approach to fisheries, Part 2: Scientific papers, FAO Fisheries Technical Paper 350/2. Rome, FAO. 191-199.

Ganguly, S., and Chaudhuri, K.S. 1995. Regulation of a single-species fishery by taxation. Ecol. Model. 82: 51-60.

Garza-Gil, D. 1998. ITQ systems in multifleet fisheries. Environ. Resour. Econ. 11: 79-92.

Gavaris, S. 1980. Use of multiplicative model to estimate catch rate and effort from commercial data. Can. J. Fish. Aquat. Sci. 37: 2272-2275.

Gillis, D.M. 2003. Ideal free distributions in fleet dynamics: a behavioral perspective on vessel movement in fisheries analysis. Can. J. Zool. 81: 177-187. 
Gillis, D.M., and Peterman, R.M. 1998. Implications of interference among fishing vessels and the ideal free distribution to the interpretation of CPUE. Can. J. Fish. Aquat. Sci. 55: 37-46.

Gordon, H.S. 1953. An economic approach to the optimum utilization of fishery resources. J. Fish. Res. Board Can. 10: 442-447.

Guyader, O., and Daurès, 2000. Economic analysis of the impact of buyback programmes and the role of financial incentives schemes: application to a limited entry French fishery. Proceedings of the XIIth Annual Conference of the European Association of Fisheries Economists, Lindebo and Vestergaard, eds., Department of Environmental and Business Economics, University of Southern Denmark, Esbjerg, Denmark, 65-90.

Guyader, O., Daurès, F., Fifas, S. 2004. A bioeconomic analysis of the impact of decommissioning programs: application to a limited-entry scallops fishery. Mar. Res. Econ. 19: 225-242.

Hannesson, R. 2007. Growth accounting in a fishery. J. Environ. Econ. Manage. 53: 364376.

Hannesson, R., Salvanes, K.G., and Squires, D. 2010. Technologican change and the tragedy of the Commons: the Lofoten fishery over 130 years.

Haynie, A.C., and Layton, D.F. 2010. An expected profit model for monetizing fishing location choices. J. of Environ. Econ. Manage. 59: 165-176.

Hilborn, R. 1985. Fleet dynamics and individual variation: why some people catch more than others. Can. J. Fish. Aquat. Sci. 42: 2-13.

Hilborn, R., and Walters, C.W. 1992. Quantitative Fisheries Stock Assessment: Choice, Dynamics, and Uncertainty. Chapman Hall. New York.

Hoff, A., and Frost, H. 2008. Modelling combined harvest and effort regulations: the case of the Dutch beam trawl fishery for plaice and sole in the North Sea. ICES J. Mar. Sci. 65: 822-831.

Holland, D.S. 2000. A bioeconomic model of marine sanctuaries on Georges Bank. Can. J. Fish. Aquat. Sci. 57: 1307-1319.

Holland, D.S. 2003. Integrating spatial management measures into traditional fishery management systems: the case of the Georges Bank multispecies groundfish fishery. ICES J. Mar. Sci. 60: 915-929.

Holland, D.S., and Herrera, G.E. 2006. Flexible catch-balancing policies for multispecies individual fishery quotas. Can. J. Fish. Aquat. Sci. 63: 1669-1685.

Holland, D.S., and Sutinen, J.G. 1999. An empirical model of fleet dynamics in New England trawl fisheries. Can. J. Fish. Aquat. Sci. 56: 253-264.

Holley, J.-F., and Marchal, P. 2004. Fishing strategy development under changing conditions: examples from the French offshore fleet fishing in the North Atlantic. ICES J. Mar. Sci. 61: 1410-1431.

Horwood, J.W., Jacobs, O.L.R., and Balance, D.J. 1990. A feed-back control law to stabilize fisheries. J. Cons. Int Explor. Mer 47 : 57-64.

Hutton, T., Mardle, S., Pascoe, S., and Clark, R.A. 2004. Modeling fishing location choice within mixed fisheries: English North Sea beam trawlers in 2000 and 2001. ICES J. Mar. Sci. 61: 1443-1452.

ICES 2003. Report of the Study Group for the Development of Fishery-based Forecasts. ICES CM2003/ACFM:08 37 pp.

ICES 2011a. Report of the Working Group on the Assessment of Demersal Stocks in the North Sea and Skagerrak (WGNSSK), 4 - 10 May 2011, ICES Headquarters, Copenhagen. ICES CM 2011/ACOM:13. 1197 pp.

ICES 2011b. Report of the Working Group on the Biology and Assessment of Deep-sea Fisheries Resources (WGDEEP), 2-8 March 2011, Copenhagen, Denmark. ICES CM 2011/ACOM:17. 889 pp.

ICES 2011c. Report of the Working Group on Elasmobranch Fishes (WGEF), 20-24 June 2011, Copenhagen, Denmark. ICES CM 2011/ACOM:19. 492 pp. 
JRC 2010. The 2010 Annual Economic Report on the European Fishing Fleet. JRC Scientific and Technical Reports. Scientific, Technical and Economic Committee for Fisheries (STECF), Ispra, Italy. Eds.: Anderson, J., and Guillen, J. SGECA 10-02, 688 pp.

Kirkley, J., Morrison, P.C.J., Cunningham, S., and Catanzano, J. 2004. Embodied and disembodied technical change in fisheries: an analysis of the Sète trawl fishery, 19851999. Environ. Resour. Econ. 29: 191-217.

Kompas, T., Dichmont, C.M., Punt, A.E., Deng, A., Che, T.N., Bishop, J., Gooday, P., Ye, Y., Zhou, S. 2010. Maximizing profits and conserving stocks in the Australian Northern Prawn Fishery. Aust. J. Agr. Resour. Econ. 54: 281-299.

Large, P.A., Diez, G., Drewery, J., Laurans, M., Pilling, G.M., Reid, D.G., Reinert, J., South, A.B., and Vinnichenko, V.I. 2010. Spatial and temporal distribution of spawning aggregations of blue ling (Molva dypterygia) west and northwest of the British Isles. ICES J. Mar. Sci. 67: 494-501.

Laurec, A., Biseau, A., and Charuau, A. 1991. Modelling technical interactions. ICES Mar. Sci. Symp. 193 : 225-236.

Little, L.R., Punt, A.E., Mapstone, B.D., Begg, G.A., Goldman, B., and Williams, A.J. 2009. An agent-based model for simulating trading of multi-species fisheries quota. Ecol. Model. 220: 3404-3412.

Longmore, C., Trueman, C.N., Neat, F., O'Gorman, E. J., Milton, J.A., and Mariani, S. 2011. Otolith geochemistry indicates life-long spatial population structuring in a deep-sea fish, Coryphaenoides rupestris. Mar. Ecol. Prog. Ser. 435: 209-224.

Lorance, P., Pawloski, L., and Trenkel, V.M. 2010. Standardizing blue ling landings per unit effort from industry haul-by-haul data using generalized additive model. ICES J. Mar. Sci. 67: 1650-1658.

Magnussen, E. 2007. Interpopulation comparison of growth patterns of 14 fish species on Faroe Bank: are all fishes on the bank fast-growing? J. Fish Biol. 71: 453-475.

Mahévas, S., and Pelletier, D. 2004. ISIS-Fish, a generic and spatially-explicit simulation tool for evaluating the impact of management measures on fisheries dynamics. Ecol. Model. 171: 65-84.

Mahévas, S., Sandon, Y., and Biseau, A. 2004. Quantification of annual variations in fishing power due to vessel characteristics: an application to the bottom-trawlers of SouthBritanny targeting anglerfish (Lophius budegassa and Lophius piscatorius). ICES J. Mar. Sci. 61: 71-83.

Marchal, P. 1997. Managing growth overfishing with multiannual compromise strategies. Can. J. Fish. Aquat. Sci. 54: 2255-2276.

Marchal, P. [ed.] 2006. Technological developments and tactical adaotations of important EU fleets (TECTAC n QLK5-2001-01291). Final project report, 651 pp (main report), 369 pp (annexes).

Marchal, P., Francis, C., Lallemand, P., Lehuta, S., Mahévas, S., Stokes, K., and Vermard, Y. 2009a. Catch-quota balancing in mixed-fisheries: a bio-economic modelling approach applied to the New Zealand hoki (Macruronus novaezelandiae) fishery. Aquat. Living Resour. 22: 483-498.

Marchal, P., Lallemand, P., and Stokes, K. 2009b. The relative weight of traditions, economics, and catch plans in New Zealand fleet dynamics. Can. J. Fish. Aquat. Sci. 66: 291-311.

Marchal, P., Little, L.R., and Thébaud, O. 2011. Quota allocation in mixed-fisheries: a bioeconomic modelling approach applied to the Channel flatfish fisheries. ICES J. Mar. Sci. 68: 1580-1591.

Maunder, M.N., and Punt, A.E. 2004. Standardizing catch and effort data: a review of recent approaches. Fish. Res. 70: 141-159.

Millischer, L., Gascuel, D., and Biseau, A. 1998. Estimation of the overall fishing power: A study of the dynamics and fishing strategies of Brittany"s industrial fleets. Aquat. Living Resour. 12: 89-103. 
Overholtz, W.J., Edwards, S.F., and Brodziak, J.K.T. 1995. Effort control in the New England groundfish fishery: a bioeconomic perspective. Can. J. Fish. Aquat. Sci. 52: 19441957.

Pascoe, S., and Robinson, C. 1996. Measuring changes in technical efficiency over time using catch and stock information. Fish. Res. 28: 305-319.

Pascoe, S., Andersen, J., and De Wilde, J.W. 2001. The impact of management regulation on the technical efficiency of vessels in the Dutch beam trawl fishery. Eur. Rev. Agr. Econ. 28: 187-206.

Pelletier, D., and Mahévas, S. 2005. Fisheries simulation models for evaluating the impact of management policies, with emphasis on marine protected areas. Fish Fish. 6: 307349.

Poos, J.-J., and Rijnsdorp, A.D. 2007. An "experiment" on effort allocation of fishing vessels: the role of interference competition and area specialization. Can. J. Fish. Aquat. Sci. 64: 304-313.

Pope, J.G., and Shepherd, J.G. 1985. A comparison of the performance of various methods for tuning VPAs using effort data. J. Cons. Int. Explor. Mer. 42: 129-151.

Pradhan, N.C., and Leung, P.S. 2004. Modeling trip choice behaviour of the longline fishers in Hawaii. Fish. Res. 68: 209-224.

Prellezo, R., Accadia, P., Andersen, J.L., Andersen, B.S., Buisman, E., Little, A., Nielsen, J.R., Poos, J.-J., Powell, J., Röckmann, C. 2012. A review of EU bio-economic models for fisheries: the value of a diversity of models. Mar. Policy 36: 423-431.

Punt, A.E., and Butterworth, D.S. 1991. On an approach for comparing the implications of alternative fish stock assessments, with application to the stock of Cape hake Merluccius spp. off Northern Namibia. S. Afr. J. Mar. Sci. 10: 219-240.

Reeves, S.A., Marchal, P., Mardle, S., Pascoe, S., Prellezo, R., Thébaud, O., and Travers, M. 2008. From fish to fisheries: the changing focus of management advice. In: Payne, A., Cotter, J., Potter [Eds], Advances in Fisheries Science. 50 years on from Beverton and Hold. Blackwell Publishing, pp. 135-154.

Rijnsdorp, A.D., Dol, W., Hoyer, M., and Pastoors, M.A. 2000. Effects of fishing power and competitive interactions among vessels on the effort allocation on the trip level of the Dutch beam trawl fleet. ICES J. Mar Sci. 57: 927-937.

Robins, C.M., Wang, Y.-G., and Die, D. 1998. The impact of global positioning systems and plotters on fishing power in the northern prawn fishery, Australia. Can. J. Fish. Aquat. Sci. 55: 1645-1651.

Sanchirico, J.N., and Wilen, J.E. 2005. Optimal spatial management of renewable resources: matching policy scope to ecosystem scale. J. Environ. Econ. Manage. 50: 23-46.

Schaefer, M.B. 1954. Some aspects of the Dynamics of the Fishery for Yellowfin Tuna in the Eastern Tropical Pacific Ocean. Bulletin of the Inter-American Tropical Tuna Commission, 2: 247-285.

Schaefer, M.B. 1957. Some considerations of population dynamics and economics in relation to the management of marine fisheries. J. Fish. Res. Board Can. 14: 669-681.

Shepherd, J.G. 1999. Extended survivors analysis: An improved method for the analysis of catch-at-age data and abundance indices. ICES J. Mar. Sci. 56: 584-591.

Smith, M.D., Zhang, J., and Coleman, F.C. 2008. Econometric modeling of fisheries with complex life histories: Avoiding biological management failures. J. Environ. Econ. Manage. 55: 265-280.

Thomas R., 1987. Biological investigations on the blue ling, Molva dypterygia dypterygia (Pennant 1784 after O.F. Mueller 1776), in the areas of the Faroe Islands and to the West of the Shetland Islands. Arch. Fischereiwiss. 38: 9-34.

Trisak, J. 2005. Applying game theory to analyse the influence of biological characteristics on fishers" cooperation in fisheries co-management. Fish. Res. 75: 164-174.

Ulrich, C., Andersen, B.S., Sparre, P.J., and Nielsen, J.R. 2007. TEMAS: fleet-based bioeconomic simulation software to evaluate management strategies accounting for fleet behavior. ICES J. Mar. Sci. 64: 647-651. 
Ulrich, C., Pascoe, S., Sparre, P.J., De Wilde, J.-W., and Marchal, P. 2002. Influence of trends in fishing power on bioeconomics in the North Sea flatfish fishery regulated by catches or by effort quotas. Can. J. Fish. Aqut. Sci. 59: 829-843.

Verissimo, A., McDowell, J.R., and Graves, J.E. 2011. Population structure of a deep-water squaloid shark, the Portuguese dogfish (Centroscymnus coelolepis). ICES J. Mar. Sci. 68: 555-563.

Vermard, Y., Mahévas, S., Marchal, P., and Thébaud, O. 2008. A fleet dynamic model of the Bay of Biscay pelagic fleet simulating métiers" choice. Can. J. Fish. Aquat. Sci. 65: 2444-2453.

White, T.A., Stamford, J., and Hoelzel, A.R. 2010. Local selection and population structure in a deep-sea fish, the roundnose grenadier (Coryphaenoides rupestris). Mol. Ecol. 19: 216-226.

Zuur, A., leno, E.N., Walker, N., Saveliev, A.A., and Smith, G.M. 2009. Mixed effects models and extensions in ecology with R. Springer, $1^{\text {st }}$ Edition, XXII, 574 pp. 
Table 1. Biological age-dependent inputs to the BEM for blue ling (Molva Dypterygia) and saithe (Pollachius virens). The average (minimum, maximum) mean weights at age observed and exploitation pattern at age estimated over the period 1999-2008 are provided. Exploitation patterns $(S)$ in any year were calculated as the ratio between fishing mortality $(F)$ at age (as output from stock assessment) and the mean $F$ averaged over all age groups. Ages 17 and 10 are plus-groups for blue ling and saithe respectively. Natural mortality $(M)$ is assumed constant across years and age groups. Initial abundance is the 1999 estimated numbers.

\begin{tabular}{|c|c|c|c|c|c|c|c|c|c|c|}
\hline \multirow[b]{2}{*}{ Stock } & \multicolumn{2}{|c|}{$\begin{array}{l}\text { Mean weight }(\mathrm{kg})(1999- \\
2008)\end{array}$} & \multicolumn{2}{|c|}{ Exploitation pattern (1999-2008) } & \multicolumn{2}{|c|}{ Maturity ogive } & \multicolumn{2}{|c|}{ Natural mortality } & \multicolumn{2}{|c|}{ Initial abundance $(, 000)$} \\
\hline & Blue ling & Saithe & Blue ling & Saithe & Blue ling & Saithe & Blue ling & Saithe & Blue ling & Saithe \\
\hline \multicolumn{11}{|l|}{ Age } \\
\hline 3 & - & $0.9(0.7-1.1)$ & - & $0.4(0.2-0.7)$ & - & 0.00 & - & 0.20 & - & 140145 \\
\hline 4 & - & $1.1(0.9-1.2)$ & - & $1.0(0.6-1.3)$ & - & 0.15 & - & 0.20 & - & 48521 \\
\hline 5 & - & $1.4(1.2-1.6)$ & - & $1.3(1.1-1.5)$ & - & 0.70 & - & 0.20 & - & 71555 \\
\hline 6 & - & $1.8(1.7-2.2)$ & - & $1.3(1.1-1.6)$ & - & 0.90 & - & 0.20 & - & 25637 \\
\hline 7 & $2.1(2.1-2.1)$ & $2.4(2.1-2.8)$ & $0.6(0.4-1.0)$ & $1.4(0.9-1.8)$ & 0.50 & 1.00 & 0.15 & 0.20 & 3952 & 27614 \\
\hline 8 & $2.6(2.6-2.6)$ & $3.2(2.6-3.6)$ & $0.8(0.5-1.1)$ & $1.5(1.0-2.3)$ & 1.00 & 1.00 & 0.15 & 0.20 & 2439 & 5127 \\
\hline 9 & $3.1(3.0-3.1)$ & $4.2(3.5-5.1)$ & $1.0(0.8-1.3)$ & $1.7(0.9-3.4)$ & 1.00 & 1.00 & 0.15 & 0.20 & 1636 & 1849 \\
\hline 10 & $3.6(3.5-3.6)$ & $5.6(4.0-7.9)$ & $1.0(0.8-1.2)$ & $1.7(0.9-3.4)$ & 1.00 & 1.00 & 0.15 & 0.20 & 1192 & 1345 \\
\hline 11 & $4.0(3.9-4.1)$ & - & $0.7(0.5-1.0)$ & - & 1.00 & - & 0.15 & - & 779 & \\
\hline 12 & $4.4(4.3-4.5)$ & - & $1.0(0.7-1.3)$ & - & 1.00 & - & 0.15 & - & 493 & \\
\hline 13 & $4.8(4.7-4.9)$ & - & $1.2(0.8-1.6)$ & - & 1.00 & - & 0.15 & - & 280 & \\
\hline 14 & $5.2(5.1-5.2)$ & - & $1.2(0.8-1.9)$ & - & 1.00 & - & 0.15 & - & 217 & \\
\hline 15 & $5.5(5.4-5.5)$ & - & $1.2(0.5-1.9)$ & - & 1.00 & - & 0.15 & - & 101 & \\
\hline 16 & $5.7(5.6-5.7)$ & - & $1.2(0.8-1.4)$ & - & 1.00 & - & 0.15 & - & 67 & \\
\hline 17 & $7.2(6.9-7.4)$ & - & $1.2(0.8-1.4)$ & - & 1.00 & - & 0.15 & - & 513 & \\
\hline
\end{tabular}


Table 2. Average (minimum, maximum) values taken by the species-dependent exogenous parameters, over the period 1999-2008. Blue ling (Molva dypterygia), roundnose grenadier (Coryphaenoides rupestris) and black scabbardfish (Aphanopus carbo) have been managed by catch quotas since 2003, and deepwater sharks (Centrophorus squamosus and Centroscymnus coelolepis) since 2005 only. Saithe (Pollachius virens) has been managed by catch quotas over the entire period. The French quota for blue ling is the sum of the quotas applied in (a) ICES Subareas VI and VII for blue ling and, (b) ICES Division Vb for blue ling and ling (Molva molva). The French quota for saithe is the sum of the quotas applied in, (a) ICES Subareas II (EC), III and IV, (b) ICES Division Vb and Subareas VI and XII and, (c) ICES Subareas VII, VIII, IX and $X$. The French quota for roundnose grenadier applies to ICES Division Vb and Subareas VI and VII. The French quota for black scabbardfish applies to ICES Subareas V, VI, VII and XII. The French quota for deepwater sharks applies to all Northeast Atlantic catches. Recruitment is at age 7 and 3 for blue ling and saithe respectively. Fish prices $(p)$ are year averages.

\begin{tabular}{|c|c|c|c|c|c|}
\hline & Blue ling & Saithe & $\begin{array}{l}\text { Roundnose } \\
\text { grenadier }\end{array}$ & $\begin{array}{l}\text { Black } \\
\text { scabbardfish }\end{array}$ & $\begin{array}{l}\text { Deepwater } \\
\text { sharks }\end{array}$ \\
\hline Recruitment in numbers $\left(10^{6}\right)$ & $3.4(2.6-4.0)$ & $129(60-194)$ & - & - & - \\
\hline $\begin{array}{l}\text { Catch proportion from large French } \\
\text { trawlers }\end{array}$ & $0.4(0.2-0.5)$ & $0.2(0.1-0.3)$ & $0.5(0.4-0.7)$ & $0.4(0.2-0.6)$ & $0.2(0.1-0.4)$ \\
\hline Catch proportion from other French fleet & $0.1(0.1-0.2)$ & $0.0(0.0-0.1)$ & $0.2(0.1-0.3)$ & $0.2(0.1-0.4)$ & $0.1(0.1-0.2)$ \\
\hline Catch proportion from non-French fleet & $0.5(0.4-0.7)$ & $0.8(0.7-0.9)$ & $0.3(0.0-0.5)$ & $0.4(0.1-0.7)$ & $0.7(0.4-0.9)$ \\
\hline French quota $\left(10^{3} \mathrm{t}\right)$ & $4.4(3.7-5.0)$ & $46(29-67)$ & $4.2(3.6-4.4)$ & $2.5(2.3-2.6)$ & $1.8(0.4-2.8)$ \\
\hline Price - $p(€ / \mathrm{kg})$ & $2.0(1.8-2.2)$ & $1.1(1.1-1.1)$ & $1.7(1.4-2.1)$ & $2.1(1.6-2.8)$ & $1.4(1.2-1.6)$ \\
\hline
\end{tabular}


Table 3. Parameters from the Schaefer model (carrying capacity $K$, growth rate $r$, initial biomass $B$ in 1999) used to parameterize the BEM for roundnose grenadier (Coryphaenoides rupestris), black scabbardfish (Aphanopus carbo) and deepwater sharks (Centrophorus squamosus and Centroscymnus coelolepis).

\section{Carrying capacity in $\mathrm{G} \quad$ Growth rate $(\mathrm{r}) \quad$ Initial biomass (t)}

$(\mathrm{K})$

\begin{tabular}{llll}
\hline Roundnose & 134301 & 0.15 & 77781 \\
grenadier & & & \\
Black scabbardfish & 60657 & 0.43 & 51400 \\
Deepwater sharks & 52890 & 0.45 & 31372 \\
\hline
\end{tabular}


Table 4. Average (minimum, maximum) values taken by available capacity and economics variables related to the two French fleets, over the period 1999-2008. "Other species" are all landed species excluding blue ling (Molva Dypterygia), saithe (Pollachius virens), roundnose grenadier (Coryphaenoides rupestris), black scabbardfish (Aphanopus carbo) and deepwater sharks (Centrophorus squamosus and Centroscymnus coelolepis). The coding in equations 1-13 is also shown when appropriate.

\begin{tabular}{|c|c|c|c|}
\hline \multirow[t]{2}{*}{ Fleet } & \multicolumn{3}{|c|}{ Parameter type } \\
\hline & Type & Coded as: & Average (Min - Max) \\
\hline \multirow[t]{6}{*}{ Large French trawlers } & Operating cost (€/hour fishing) & $\chi$ & $2318(1748-4196)$ \\
\hline & Annual profit $\left(10^{6} €\right)$ & $\Pi$ & $-16(-115-+2)$ \\
\hline & Proportion of other species in gross & $\mu$ & $0.32(0.25-0.36)$ \\
\hline & revenue & & \\
\hline & No. vessels & $\mathrm{W}$ & $17(13-25)$ \\
\hline & Average hours fishing/vessel & $\Lambda$ & $2111(1619-3286)$ \\
\hline \multirow[t]{3}{*}{ Other French fleet } & No. vessels & & $3199(2683-3393)$ \\
\hline & & W & \\
\hline & Average hours fishing/vessel & $\Lambda$ & $567(411-881)$ \\
\hline
\end{tabular}


Table 5. Average (minimum, maximum) proportion of fishing effort $(\theta)$ allotted by two French fleets to the ten métiers operated, over the period 1999-2008; target factor quantifying how strongly each species is targeted by each metier (the average between the two fleets is given first, followed by the value for each of the two French fleets in bracket). DeepEdge6, DeepNew5, DeepNew6, DeepOther6, DeepRef5 and DeepRef7 refer to the deepwater métiers (fishing grounds) identified by Lorance et al. (2010). Dem4, Dem5, Dem6 and Dem78 are the other demersal métiers operated by the two French fleets in shallower waters.

\begin{tabular}{|c|c|c|c|c|c|c|c|c|c|}
\hline \multicolumn{2}{|r|}{ Métiers } & \multicolumn{3}{|c|}{ Proportion of effort } & \multicolumn{5}{|c|}{ Target factor } \\
\hline Code & Full name & $\begin{array}{l}\text { Large French } \\
\text { trawlers }\end{array}$ & $\begin{array}{r}\text { Other } \\
\mathrm{fl}\end{array}$ & $\begin{array}{l}\text { rench } \\
\text { et }\end{array}$ & Blue ling & Saithe & $\begin{array}{l}\text { Black } \\
\text { scabbardfish }\end{array}$ & $\begin{array}{l}\text { Roundnose } \\
\text { grenadier }\end{array}$ & $\begin{array}{l}\text { Deepwater } \\
\text { sharks }\end{array}$ \\
\hline Dem4 & Demersal fishing in ICES Subarea IV & $0.29(0.12-0.39)$ & $\begin{array}{l}0.03 \\
0.04)\end{array}$ & $(0.02-$ & $0(0-0)$ & $\begin{array}{ll}325 & (5- \\
645) & \end{array}$ & $0(0-0)$ & $0(0-0)$ & $0(0-0)$ \\
\hline Dem5 & Demersal fishing in ICES Subarea $V$ & $0.01(0.00-0.02)$ & $\begin{array}{l}0.00 \\
0.00)\end{array}$ & $(0.00-$ & $6(6-6)$ & $41(11-72)$ & $1(0-2)$ & $4(0-9)$ & $12(2-23)$ \\
\hline Dem6 & Demersal fishing in ICES Subarea VI & $0.04(0.02-0.06)$ & $\begin{array}{l}0.00 \\
0.00)\end{array}$ & $(0.00-$ & $11(7-14)$ & $30(10-51)$ & $22(11-33)$ & $27(11-43)$ & $9(6-12)$ \\
\hline Dem78 & $\begin{array}{l}\text { Demersal fishing in ICES Subareas VII \& } \\
\text { VIII }\end{array}$ & $0.01(0.00-0.04)$ & $\begin{array}{l}0.94 \\
0.95)\end{array}$ & $(0.92-$ & $1(0-1)$ & $0(0-0)$ & $16(0-33)$ & $7(0-15)$ & $10(0-20)$ \\
\hline DeepEdge6 & Edge in Subarea VI & $0.18(0.11-0.27)$ & $\begin{array}{l}0.02 \\
0.02)\end{array}$ & $(0.01-$ & $21(10-33)$ & $23(9-36)$ & $24(12-35)$ & $31(15-46)$ & $12(7-18)$ \\
\hline DeepNew5 & New grounds in ICES Subarea $V$ & $0.05(0.00-0.09)$ & $\begin{array}{l}0.00 \\
0.00)\end{array}$ & $(0.00-$ & $37(17-57)$ & $0(0-0)$ & $6(3-8)$ & $55(40-70)$ & $16(10-22)$ \\
\hline DeepNew6 & New grounds in ICES Subarea VI & $0.07(0.01-0.15)$ & $\begin{array}{l}0.00 \\
0.00)\end{array}$ & $(0.00-$ & $36(23-49)$ & $0(0-0)$ & $9(4-15)$ & $102(39-165)$ & $41(28-54)$ \\
\hline DeepOther6 & Other deepwater grounds in Subarea VI & $0.21(0.18-0.25)$ & $\begin{array}{l}0.00 \\
0.00)\end{array}$ & $(0.00-$ & $29(17-41)$ & $10(5-15)$ & $42(21-62)$ & $38(21-54)$ & $13(6-20)$ \\
\hline DeepRef5 & $\begin{array}{l}\text { Reference deepwater grounds in } \\
\text { Subarea V }\end{array}$ & $0.12(0.08-0.16)$ & $\begin{array}{l}0.00 \\
0.00)\end{array}$ & $(0.00-$ & $\begin{array}{l}71 \\
101)\end{array}$ & $2(2-2)$ & $10(7-12)$ & $37(7-67)$ & $8(2-14)$ \\
\hline DeepRef7 & $\begin{array}{l}\text { Reference deepwater grounds in } \\
\text { Subarea VII }\end{array}$ & $0.02(0.00-0.06)$ & $\begin{array}{l}0.01 \\
0.01)\end{array}$ & (0.01- & $4(1-8)$ & $1(0-1)$ & $25(5-45)$ & $27(9-45)$ & $16(2-30)$ \\
\hline
\end{tabular}


Table 6. Summary of the key endogenous and exogenous processes built in the bioeconomic model developed in this study. The coding used in equations 1-13 is shown in brackets where appropriate. Different biological processes are built in for, $\left({ }^{*}\right)$ age-structured modelled species blue ling (Molva Dypterygia) and saithe (Pollachius virens) and, $\left({ }^{* *}\right)$ production modelled species roundnose grenadier (Coryphaenoides rupestris), black scabbardfish (Aphanopus carbo) and deepwater sharks (Centrophorus squamosus and Centroscymnus coelolepis).

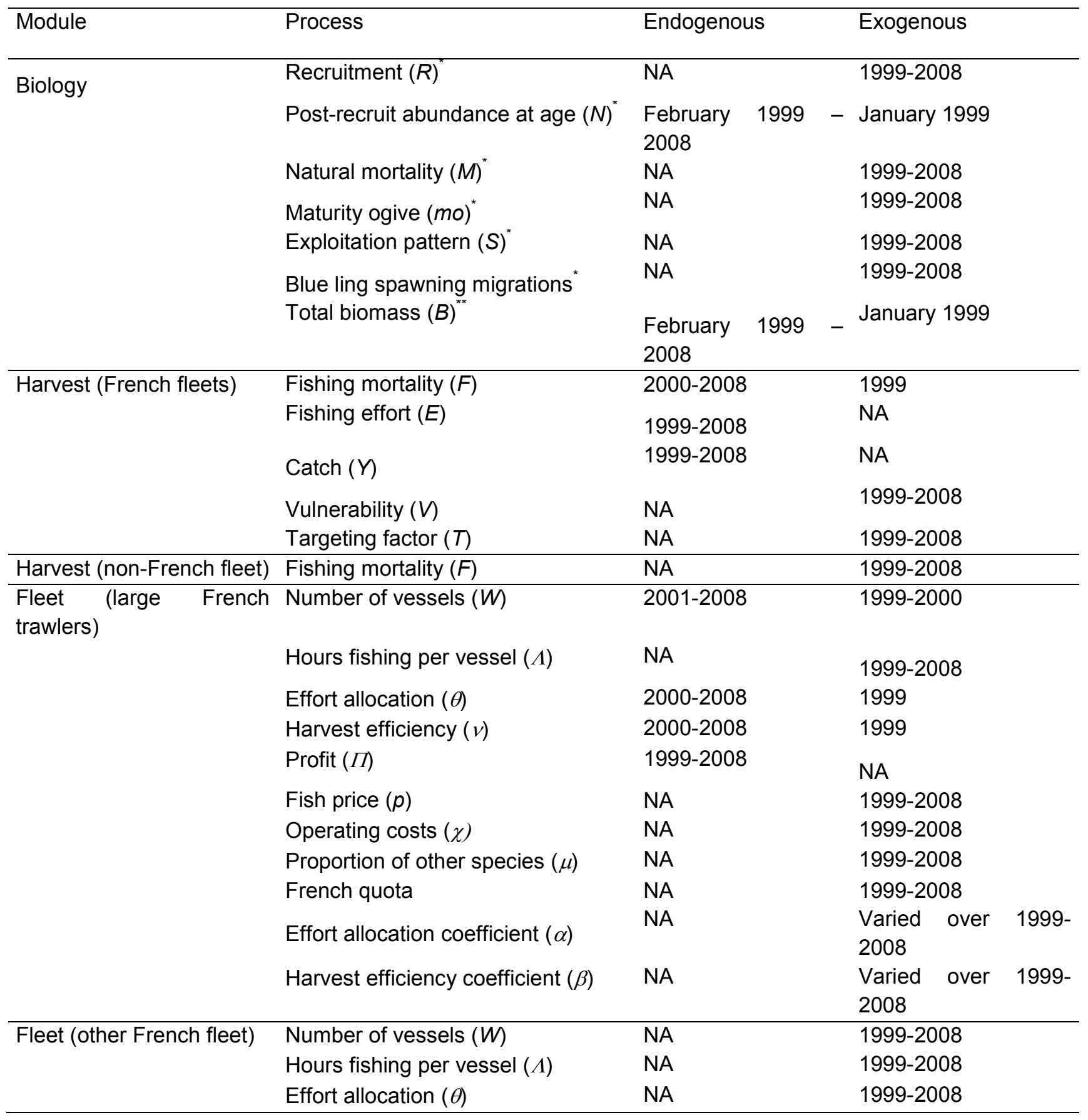




\section{Figures}

Figure 1. Contour plots showing the fleet dynamics value added index (FDVAI) as a function of the effort allocation coefficient $(\alpha)$ and of the harvest efficiency coefficient $(\beta)$. Values of FDVAl lower than 1 indicate that building in dynamic effort allocation and harvest efficiency $(\alpha>0$ and $\beta>0$ ) improves the quality of model forecast compared to a no fleet dynamics model ( $\alpha=0$ and $\beta=0$ ), and the lower the better. When FDVAI increases above 1, the precision of model forecast is adversely altered with fleet dynamics built in. FDVAI is shown for total annual catches of (a) blue ling, (b) saithe, (c) roundnose grenadier, (d) black scabbardfish and, (e) deepwater sharks, as achieved by the large French trawlers.
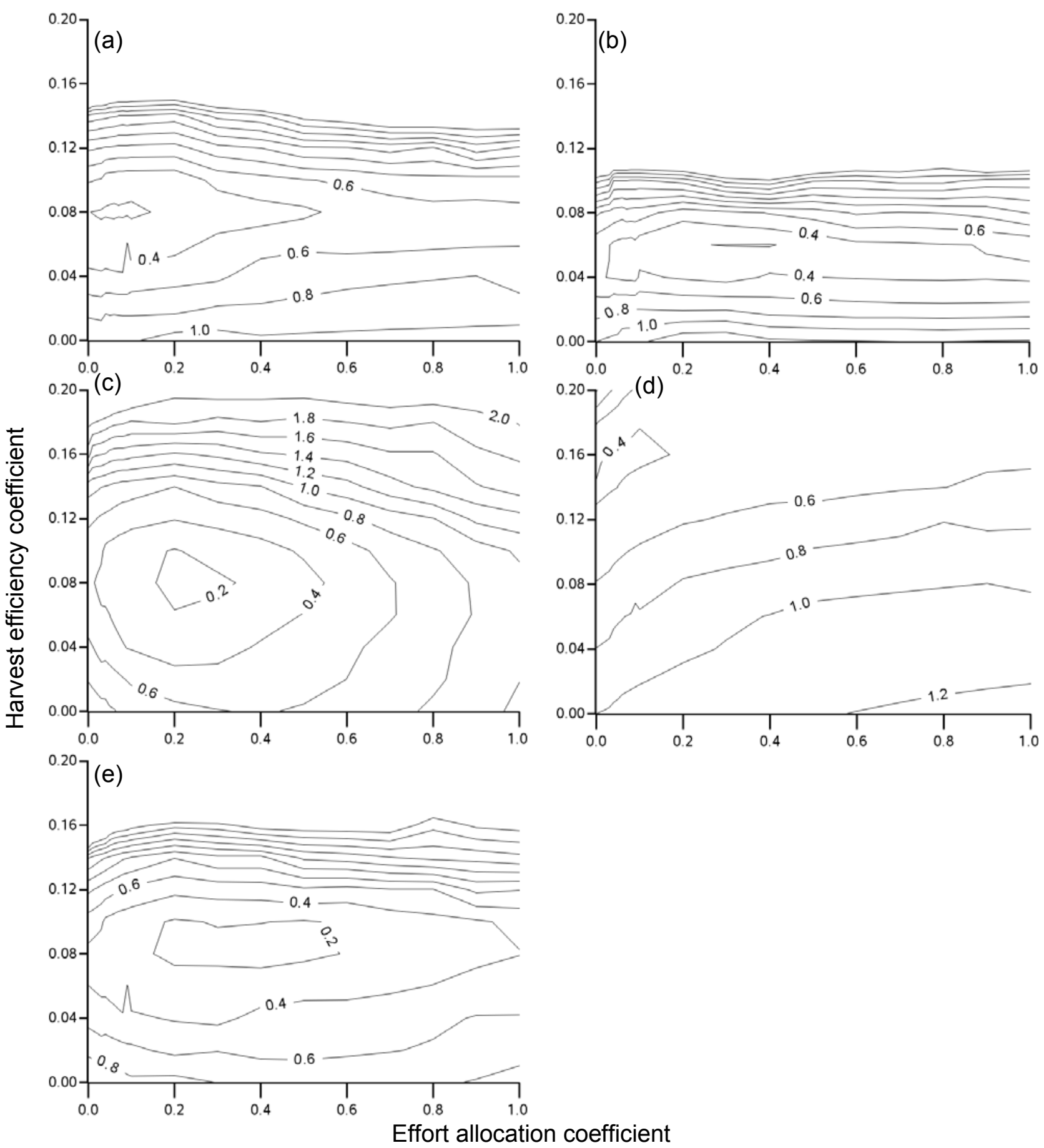
Figure 2. Contour plots showing the fleet dynamics value added index (FDVAl) as a function of the effort allocation coefficient $(\alpha)$ and of the harvest efficiency coefficient $(\beta)$. Values of FDVAI lower than 1 indicate that building in dynamic effort allocation and harvest efficiency ( $\alpha>0$ and $\beta>0$ ) improves the quality of model forecast compared to a no fleet dynamics model $(\alpha=0$ and $\beta=0$ ), and the lower the better. When FDVAI increases above 1 , the precision of model forecast is adversely altered with fleet dynamics built in. FDVAI is shown for (a) total annual fishing effort and, (b) total annual profit, as achieved by the large French trawlers.
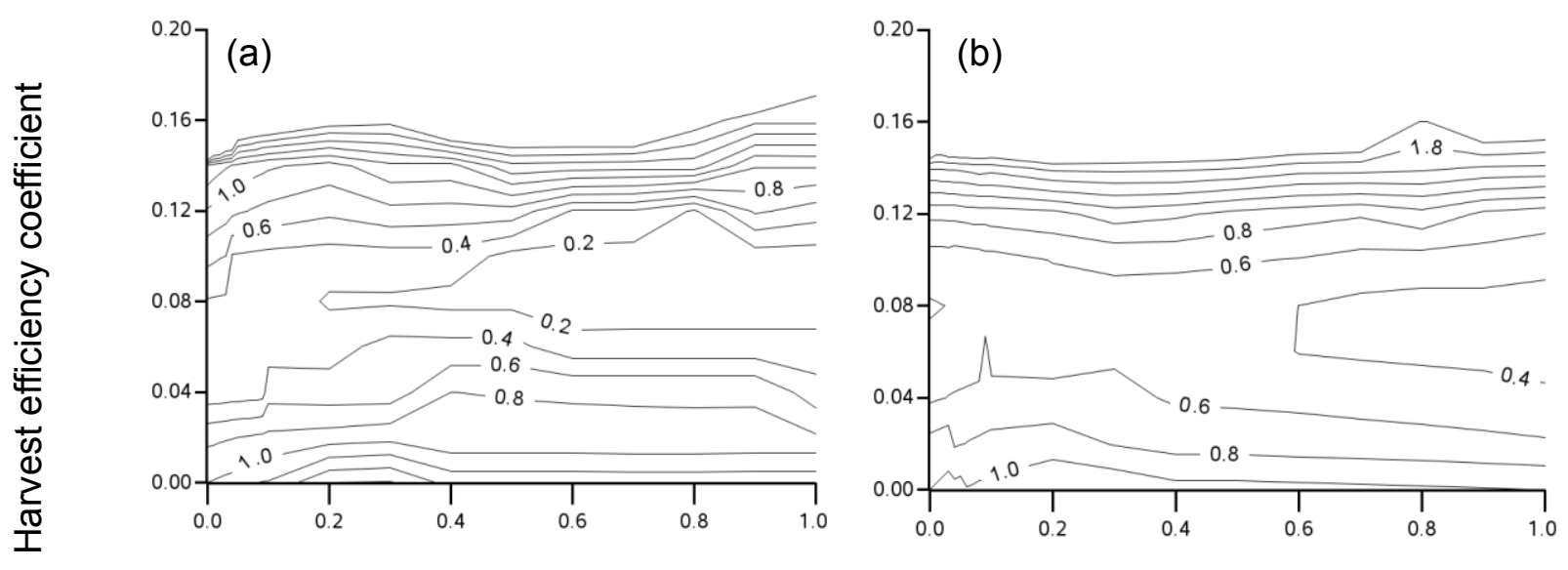

Effort allocation coefficient 
Figure 3. Contour plots showing the fleet dynamics value added index (FDVAl) as a function of the effort allocation coefficient $(\alpha)$ and of the harvest efficiency coefficient $(\beta)$. Values of FDVAI lower than 1 indicate that building in dynamic effort allocation and harvest efficiency ( $\alpha>0$ and $\beta>0$ ) improves the quality of model forecast compared to a no fleet dynamics model ( $\alpha=0$ and $\beta=0$ ), and the lower the better. When FDVAI increases above 1 , the precision of model forecast is adversely altered with fleet dynamics built in. FDVAl is shown for (a-e) annual and monthly catches by métier of, (a) blue ling, (b) saithe, (c) roundnose grenadier, (d) black scabbardfish, (e) deepwater sharks and; (f) annual and monthly fishing effort by métier, as achieved by the large French trawlers.

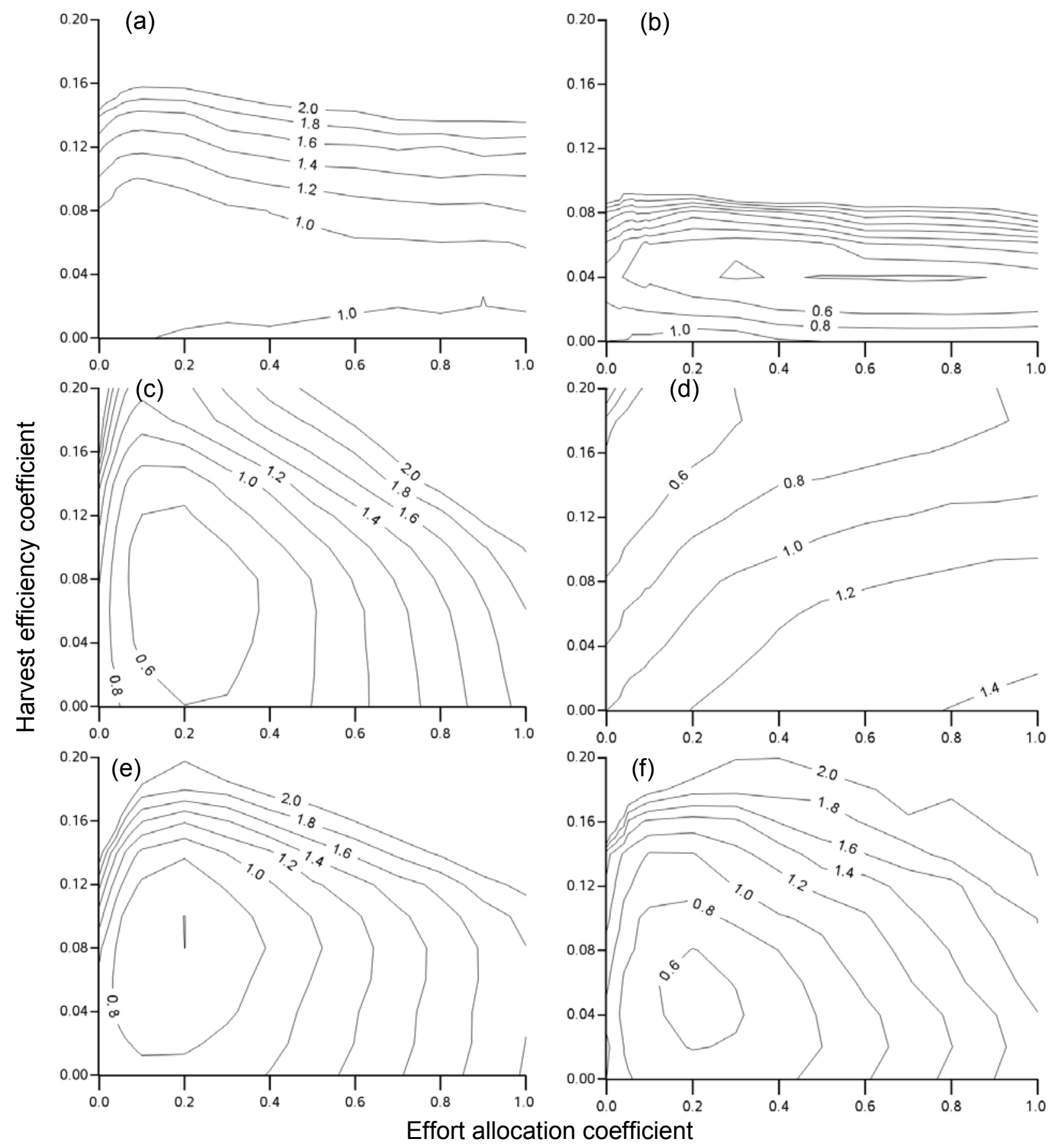


Figure 4. Simulated monthly ratios between the realized and anticipated relative profits by métier (thick plain line: median value; thick dotted lines: $5 \%$ and $95 \%$ percentiles); simulated monthly ratios between the current and the previous year relative fishing effort by métier (thin plain line: median value; thin dotted lines: $5 \%$ and $95 \%$ percentiles). The ratios are averaged ober the whole simulated period. The different metiers being considered are (a) DeepEdge6, (b) DeepOther6, (c) DeepRef5, (d) Dem4, (e) all other métiers (Dem5, Dem6, Dem78, DeepNew5, DeepNew6, DeepRef7), as operated by the large French trawlers. $\beta$ has been set to $8 \%$ per year, $\alpha$ has been set at 0.20 in the simulation forecasts shown here.
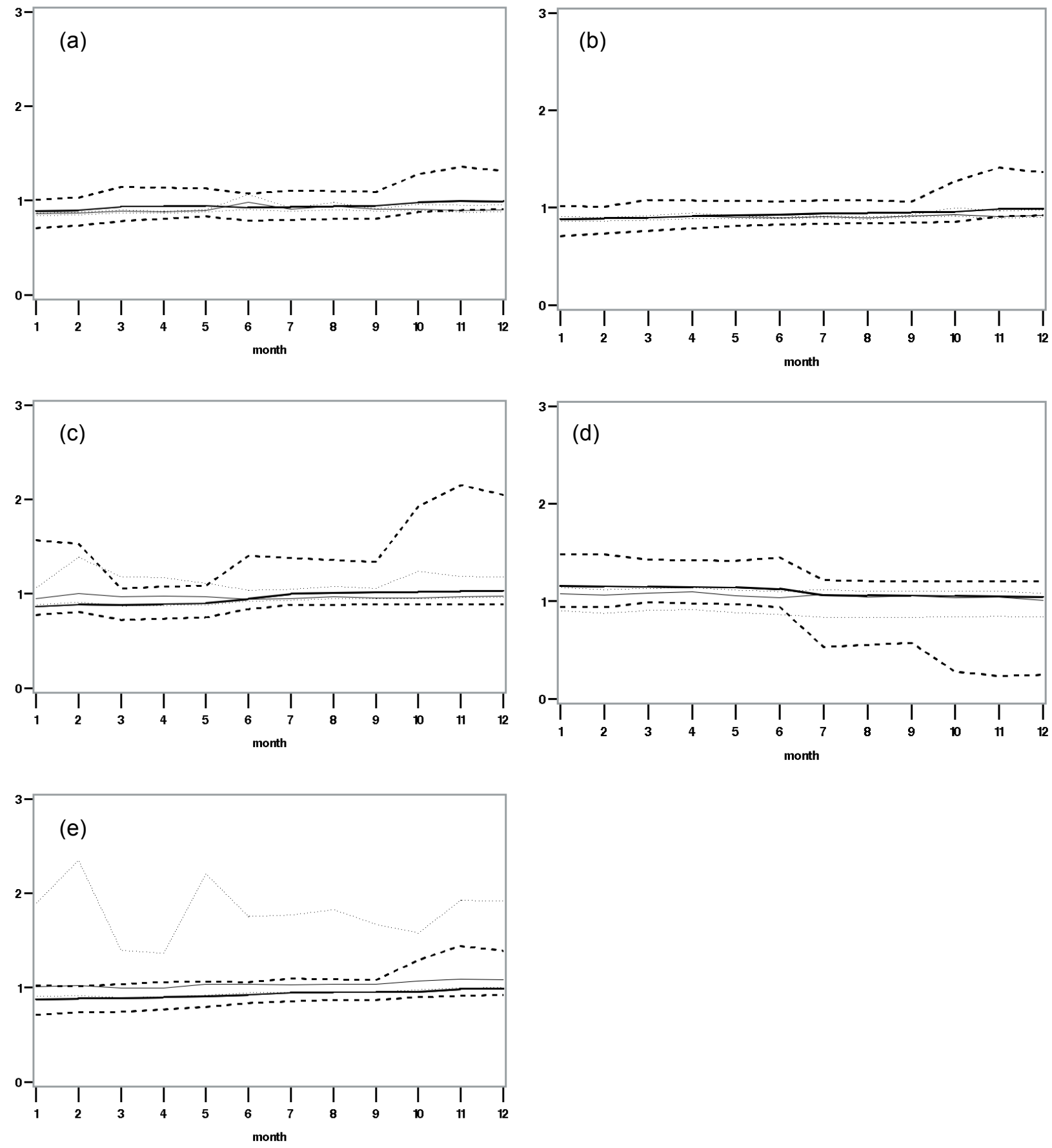
Figure 5. Time series of, (a) total annual fishing effort, (b-f) annual and monthly fishing effort allotted to, (b) métier DeepEdge6, (c) métier DeepOther6, (d) métier DeepRef5, (e) métier Dem4, (f) all other métiers (Dem5, Dem6, Dem78, DeepNew5, DeepNew6, DeepRef7) as operated by the large French trawlers. Observations are shown as dots. Forecast are represented by thin dotted lines ( $\beta=4 \%$ per year), thick plain lines $(\beta=8 \%)$ and thin plain lines $(\beta=12 \%)$. The effort allocation coefficient $\alpha$ has been set at 0.20 for the three simulation forecasts shown here. Fishing effort is expressed in hours fishing.
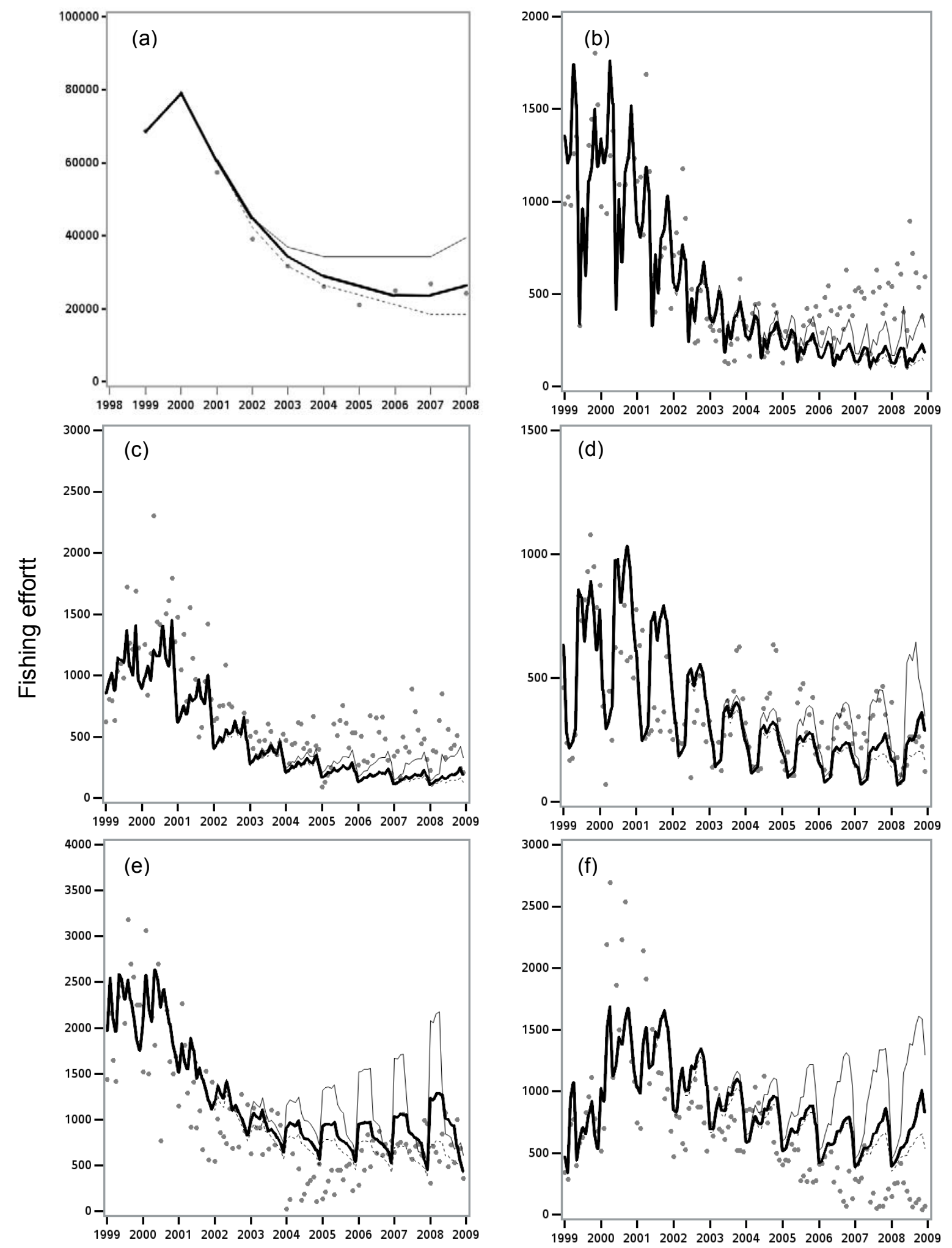
Figure 6. Time series of, (a) total annual profit (million euros), (b-f) annual and monthly catches (tonnes) of, (b) blue ling, (c) saithe, (d) roundnose grenadier, (e) black scabbardfish, (f) deepwater sharks, as achieved by the large French trawlers. Observations are shown as dots. Forecasts are represented by thin dotted lines ( $\beta=4 \%$ per year), thick plain lines $(\beta=$ $8 \%)$ and thin plain lines $(\beta=12 \%)$. The effort allocation coefficient $\alpha$ has been set at 0.20 for the three simulation forecasts shown here. Fishing effort is expressed in hours fishing.
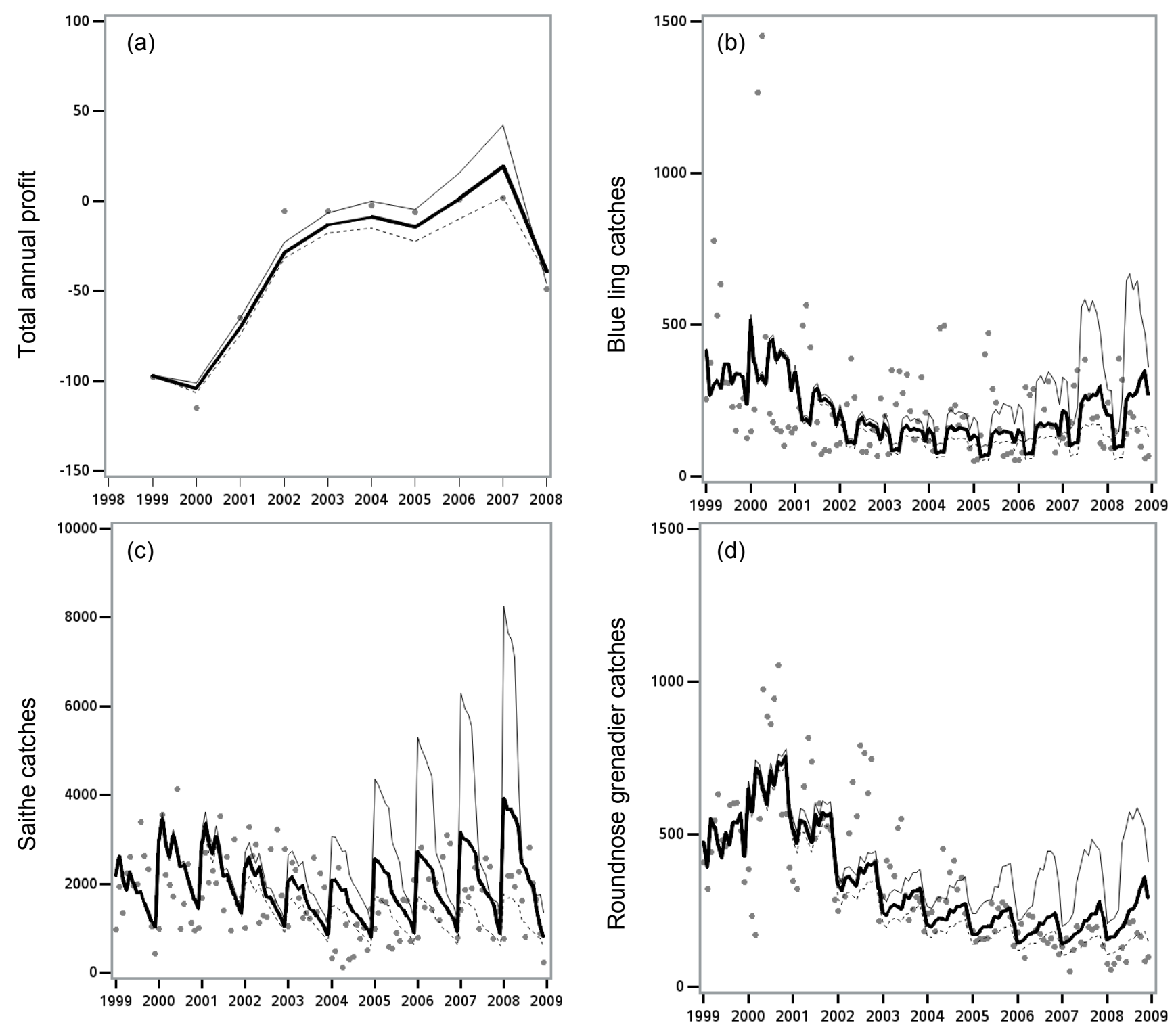

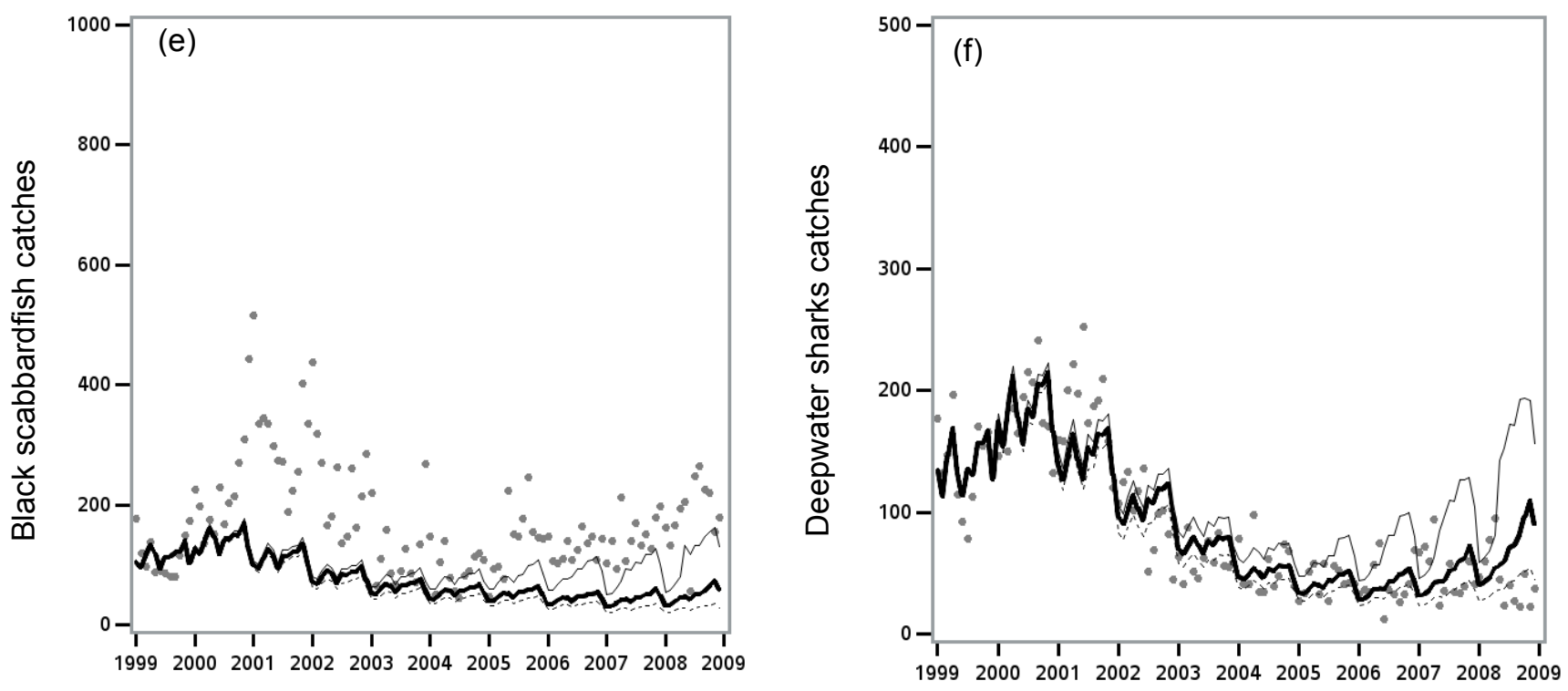

39 